\title{
Size Distribution of Multi-phase Deoxidation Particles for Heterogeneous Crystallization of TiN and Solidification Structure in Ti-Added Ferritic Stainless Steel
}

\author{
Akihisa ITO, ${ }^{1)}$ Hideaki SUITO ${ }^{2)}$ and Ryo INOUE ${ }^{1)}$ \\ 1) Institute of Multidisciplinary Research for Advanced Materials, Tohoku University, Katahira, Aoba-ku, Sendai, Miyagi-ken, \\ 980-8577 Japan. $\quad$ 2) Professor Emeritus, Tohoku University, Katahira, Aoba-ku, Sendai, Miyagi-ken, $980-8577$ Japan.
}

(Received on December 19, 2011; accepted on March 5, 2012)

\begin{abstract}
Single (Ti and $\mathrm{Mg}$ ) and multiple (Ti/M: $M=\mathrm{Mg}, \mathrm{Ca}, \mathrm{Zr}$ or $\mathrm{Ce}$ and $\mathrm{Ti} / \mathrm{M} / \mathrm{M}^{\prime}$ : Ti/Mg/Al, Al/Mg/Ti, $\mathrm{Al} / \mathrm{Ti} / \mathrm{Ca}$, Ti/ $\mathrm{Al}(\mathrm{Ca}) / \mathrm{Ca}(\mathrm{Al}), \mathrm{Ti} / \mathrm{Mg}(\mathrm{Ca}) / \mathrm{Ca}(\mathrm{Mg}), \mathrm{Ti} / \mathrm{Zr} / \mathrm{Ca}(\mathrm{Mg})$ or Ti/Ce/(Ca) deoxidations were carried out at $1600^{\circ} \mathrm{C}$ to study the effect of TiN crystallization on the solidification structure in an $\mathrm{Fe}-17.5(11) \% \mathrm{Cr}-0.25 \% \mathrm{Mn}-0.20 \% \mathrm{Si}-0.2$ to $0.3 \% \mathrm{Ti}-0.01 \% \mathrm{C}$ alloy containing 0.0030 to $0.04 \mathrm{ppm} \mathrm{N}$ on a mass percent basis. Planar size distributions of TiN, TiN+oxide and oxide particles above $1.5 \mu \mathrm{m}$ in size and spatial size distributions of particles with different compositions greater than $0.1 \mu \mathrm{m}$ in size were measured and the characteristics of these size distributions have been discussed. The crystallization and precipitation of TiN and TiN on oxide particles were studied as functions of particle number, [Ti]·[N] solubility product and composition of the deoxidation particles. It was found that the solidification structure was not influenced by the number of TiN and TiN+oxide particles of size greater than $1.5 \mu \mathrm{m}$, but by the deoxidation method. A very fine structure was observed in $\mathrm{Ti} / \mathrm{Mg}$, Ti/Mg/Al and Ti/Mg(Ca)/Mg(Ca) deoxidations and a fine structure was observed in Ti(Al)/Al(Ti)/Ca deoxidation using a $\mathrm{MgO}$ crucible both with and without the presence of $\mathrm{CaO}-\mathrm{MgO}-\mathrm{Al}_{2} \mathrm{O}_{3}$ slag.
\end{abstract}

KEY WORDS: ferritic stainless steel; TiN crystallization; primary and secondary deoxidation product; particle size distribution.

\section{Introduction}

Research on the solidification structure of ferritic stainless steel indicates that an increase in the fraction of equiaxed grains is effective for preventing the surface roughness phenomenon called ridging, which occurs after tensile deformation.

The grain refinement in an $\mathrm{Fe}-17 \% \mathrm{Cr}$ (\% represents mass $\%$ hereafter) ferritic stainless steel has been studied with focus on the $\delta$-phase nucleation in TiN. ${ }^{1,2}$ The solidification structure in an $\mathrm{Fe}-16 \% \mathrm{Cr}-0.15 \% \mathrm{Ti}-0.009 \% \mathrm{~N}$ alloy has been studied by using the complex particles in which the TiN phase crystallizes on the $\mathrm{MgO} \cdot \mathrm{Al}_{2} \mathrm{O}_{3}$ spinel phase crystallized from liquid $\mathrm{Al}-\mathrm{Mg}-\mathrm{Ti}$ oxide particles. ${ }^{3)}$

In the control of the solidification structure through the use of nucleating particles such as TiN and complex TiN+oxide (denoted as simply "complex particles" hereafter), the number of these particles is important, in addition to the nucleation potency under a given solidification condition. It was experimentally confirmed that critical undercooling in $\mathrm{Fe}$ and $\mathrm{Fe}-19 \% \mathrm{Cr}-2 \% \mathrm{Mo}$ alloys with $\delta$-phase solidification decreased as the crystallized content of TiN at the melting point $\left.{ }^{4}\right)$ increased. However, the number of small crystallized TiN particles is difficult to increase as the contents of $\mathrm{Ti}$ and $\mathrm{N}$ increase, because the coagulation of TiN particles easily occurs by collision. It is well known that an increase in the size of crystallized TiN particles causes nozzle clogging and defects in the product, if they are present in a large amount.

The effect of the deoxidation products of $\mathrm{Al}_{2} \mathrm{O}_{3}, \mathrm{ZrO}_{2}$,
$\mathrm{Ce}_{2} \mathrm{O}_{3}$ or $\mathrm{MgO}$ particles with the mean diameter of 0.8 to 1.5 $\mu \mathrm{m}$ on the crystallization and/or precipitation of TiN during solidification and holding at $1400^{\circ} \mathrm{C}$ has been studied for an $\mathrm{Fe}-10 \% \mathrm{Ni}$ alloy containing 15 to $900 \mathrm{ppm} \mathrm{Ti}$ and 200 to 290 ppm N. ${ }^{5)}$ The number of TiN+MgO particles per unit area is considerably higher than that of the $\mathrm{TiN}+M_{x} \mathrm{O}_{y}$ $(M=\mathrm{Al}, \mathrm{Zr}$ or $\mathrm{Ce})$ particles, whereas the mean diameter of the $\mathrm{TiN}+\mathrm{MgO}$ particles is smaller than that of the $\mathrm{TiN}+M_{x} \mathrm{O}_{y}$ particles. These results, which are explained by the lattice disregistry between TiN and oxide, suggest that the $\mathrm{MgO}$ phase is a candidate for the crystallization of TiN. It is to be noted that the size distribution of only the crystallized $\mathrm{TiN}+$ oxides particles cannot be estimated from the total size distribution of particles consisting of crystallized and precipitated TiN and TiN+oxide particle, and oxide particles. Therefore, the effects of the number of particles and the nucleation potency on the solidification structure cannot be clarified without solving this problem.

In the present study, single ( $\mathrm{Ti}$ and $\mathrm{Mg}$ ) and multiple ( $\mathrm{Ti} / M$ : $M=\mathrm{Mg}, \mathrm{Ca}, \mathrm{Zr}$ or Ce and $\mathrm{Ti} / M / M^{\prime}: \mathrm{Ti} / \mathrm{Mg} / \mathrm{Al}, \mathrm{Al} / \mathrm{Mg} / \mathrm{Ti}, \mathrm{Ti} /$ $\mathrm{Al}(\mathrm{Ca}) / \mathrm{Ca}(\mathrm{Al}), \mathrm{Al} / \mathrm{Ti} / \mathrm{Ca}, \mathrm{Ti} / \mathrm{Mg}(\mathrm{Ca}) / \mathrm{Ca}(\mathrm{Mg}), \mathrm{Ti} / \mathrm{Zr} / \mathrm{Ca}(\mathrm{Mg})$ and $\mathrm{Ti} / \mathrm{Ce} / \mathrm{Ca}$ ) deoxidations were carried out at $1600^{\circ} \mathrm{C}$ in order to study the effect of TiN crystallization on the solidification structure in an $\mathrm{Fe}-17.5(11) \% \mathrm{Cr}-0.25 \% \mathrm{Mn}-$ $0.20 \% \mathrm{Si}-0.2$ to $0.3 \% \mathrm{Ti}-0.01 \% \mathrm{C}$ alloy containing 30 to 400 $\mathrm{ppm} \mathrm{N}$. An alumina or magnesia crucible was used in either the presence or absence of $\mathrm{CaO}-\mathrm{MgO}-\mathrm{Al}_{2} \mathrm{O}_{3}$ slag. The size distributions of $\mathrm{TiN}, \mathrm{TiN}+$ oxide and oxide particles were measured by using cross section and electrolytic extraction methods. The characteristics of these methods and the limita- 
tions of separation of primary and secondary particles are discussed, together with the effect of the presence of slag on the TiN crystallization. The effect of number of TiN, TiN+oxide and oxide particles measured by the cross section method on the solidification structure is mainly discussed in this study. The effect of particle composition on the solidification structure is discussed in a separate paper. ${ }^{6}$

\section{Experimental}

\subsection{Deoxidation Methods with and without Slag}

Deoxidation experiments were carried out in an induction furnace $(100 \mathrm{kHz})$ in an Ar atmosphere. A graphite susceptor with $10 \mathrm{~mm}$ thickness was installed between the induction coil and the crucible to eliminate induction stirring of the melt. A charge was prepared by mixing high-purity electrolytic iron (99.99\%), Fe-75\%Cr, Fe-76\% Si, Fe-5\%C and $\mathrm{Mn}$. An Fe$76 \% \mathrm{Ti}, \mathrm{Ni}-16 \% \mathrm{Mg}, \mathrm{Ni}-10 \% \mathrm{Ca}, \mathrm{Fe}-76 \% \mathrm{Zr}, \mathrm{Fe}-50 \% \mathrm{Al}$ and $\mathrm{Fe}-50 \% \mathrm{Ce}$ alloys, which were prepared previously by melting in an arc furnace, were used as deoxidants. The $\mathrm{Fe}-6.3 \% \mathrm{~N}$ mixture and $\mathrm{Fe}-0.12 \% \mathrm{O}$ alloy were used to control the initial and intermediate contents of $\mathrm{N}$ and $\mathrm{O}$, respectively.

An $\mathrm{Fe}-17.5(11) \% \mathrm{Cr}-0.25 \% \mathrm{Mn}-0.20 \% \mathrm{Si}-0.01 \% \mathrm{C}$ alloy $(200 \mathrm{~g})$ was melted at $1600^{\circ} \mathrm{C}$ in a high-purity $\mathrm{Al}_{2} \mathrm{O}_{3}$ or $\mathrm{MgO}$ crucible. After holding for $20 \mathrm{~min}$ at this temperature for homogenization of the metal composition, the melt with initial $\mathrm{O}$ and $\mathrm{N}$ contents was deoxidized using various deoxidants. After stirring for $20 \mathrm{~s}$ using an $\mathrm{Al}_{2} \mathrm{O}_{3}$ rod, the melt was held for $1 \mathrm{~min}$ at $1600^{\circ} \mathrm{C}$ and cooled to $1400^{\circ} \mathrm{C}(1450$ and $1200^{\circ} \mathrm{C}$ ) at a rate of $5^{\circ} \mathrm{C} / \mathrm{min}$ or to $450^{\circ} \mathrm{C}$ at a rate of $2.5^{\circ} \mathrm{C} / \mathrm{min}$, followed by quenching. The deoxidation methods without slag are summarized in Table 1. It is reported that the equilibrium $\mathrm{N}$ content is 90 (100) ppm at $\mathrm{Ti}=0.3 \%$ in an $\mathrm{Fe}-10 \% \mathrm{Cr}$ alloy at $1550^{\circ} \mathrm{C}$. $^{7)}$

In Exps. 9, 10, 34, 35 and 38, the melt was held for 1, 5 or 10 minutes at $1540^{\circ} \mathrm{C}$ to promote the crystallization of TiN on the oxide particles. In Exps. 22, 26, 27, 34 to 39, 57

Table 1. Deoxidation experiments without slag.

\begin{tabular}{|c|c|}
\hline Exp. No. & Deoxidant \\
\hline & $\mathrm{Ti}$ \\
\hline $1 *$ & $0.3 \% \mathrm{Ti}\left(1400^{\circ} \mathrm{C}\right)$ \\
\hline 2 & $0.2 \% \mathrm{Ti}\left(450^{\circ} \mathrm{C}\right)$ \\
\hline 3 & $0.2 \% \mathrm{Ti}\left(450^{\circ} \mathrm{C}\right)$ \\
\hline 4 & $0.2 \% \mathrm{Ti}\left(1400^{\circ} \mathrm{C}\right)$ \\
\hline \multirow[t]{2}{*}{5} & $0.02 \% \mathrm{Al}-30 \mathrm{~min}-0.2 \% \mathrm{Ti}\left(1400^{\circ} \mathrm{C}\right)$ \\
\hline & $\mathrm{Mg}$ \\
\hline 6 & $0.1 \% \mathrm{Mg}\left(450^{\circ} \mathrm{C}\right)$ \\
\hline \multirow[t]{2}{*}{7} & $0.1 \% \mathrm{Mg}\left(450^{\circ} \mathrm{C}\right)$ \\
\hline & $\mathrm{Ti} / \mathrm{Mg}$ \\
\hline $8 *$ & $0.3 \% \mathrm{Ti} / 0.1 \% \mathrm{Mg}\left(1400^{\circ} \mathrm{C}\right)$ \\
\hline $9 * \mathrm{M}$ & $0.25 \% \mathrm{Ti} / 0.1 \% \mathrm{Mg}-1540^{\circ} \mathrm{C}, 5 \min \left(1400^{\circ} \mathrm{C}\right)$ \\
\hline $10 * \mathrm{M}$ & $0.25 \% \mathrm{Ti} / 0.1 \% \mathrm{Mg}-1540^{\circ} \mathrm{C}, 1 \min \left(1400^{\circ} \mathrm{C}\right)$ \\
\hline 11 & $0.2 \% \mathrm{Ti} / 0.1 \% \mathrm{Mg}\left(1400^{\circ} \mathrm{C}\right)$ \\
\hline 12 & $0.2 \% \mathrm{Ti} / 0.1 \% \mathrm{Mg}\left(1400^{\circ} \mathrm{C}\right)$ \\
\hline 13 & $0.2 \% \mathrm{Ti} / 0.1 \% \mathrm{Mg}\left(1400^{\circ} \mathrm{C}\right)$ \\
\hline 14 & $0.2 \% \mathrm{Ti} / 0.1 \% \mathrm{Mg}\left(1200^{\circ} \mathrm{C}\right)$ \\
\hline 15 & $0.2 \% \mathrm{Ti} / 0.1 \% \mathrm{Mg}-30 \min \left(1400^{\circ} \mathrm{C}\right)$ \\
\hline 16 & $0.2 \% \mathrm{Ti} / 0.1 \% \mathrm{Mg}\left(1400^{\circ} \mathrm{C}\right)$ \\
\hline 17 & $0.1 \% \mathrm{Ti} / 0.05 \% \mathrm{Mg} / 0.1 \% \mathrm{Ti} / 0.05 \% \mathrm{Mg}\left(1400^{\circ} \mathrm{C}\right)$ \\
\hline \multirow[t]{2}{*}{18} & $0.1 \% \mathrm{Ti} / 0.1 \% \mathrm{Mg} / 0.1 \% \mathrm{Ti}-1400^{\circ} \mathrm{C}, 60 \min \left(1400^{\circ} \mathrm{C}\right)$ \\
\hline & $\mathrm{Al} / \mathrm{Mg} / \mathrm{Ti}$ and $\mathrm{Ti} / \mathrm{Mg} / \mathrm{Al}$ \\
\hline $19 *$ & $0.05 \% \mathrm{Al} / 0.1 \% \mathrm{Mg} / 0.3 \% \mathrm{Ti}\left(1400^{\circ} \mathrm{C}\right)$ \\
\hline 20 & $0.2 \% \mathrm{Ti} / 0.1 \% \mathrm{Mg} / 0.003 \% \mathrm{Al}\left(1200^{\circ} \mathrm{C}\right)$ \\
\hline
\end{tabular}

Table 1. Continue.

\begin{tabular}{|c|c|}
\hline Exp. No. & \multirow[t]{2}{*}{ Deoxidant } \\
\hline & \\
\hline $21 *$ & $0.3 \% \mathrm{Ti} / 0.1 \% \mathrm{Ca}\left(1400^{\circ} \mathrm{C}\right)$ \\
\hline 22 & $0.005 \% \mathrm{O} / 0.2 \% \mathrm{Ti} / 0.1 \% \mathrm{Ca}\left(1400^{\circ} \mathrm{C}\right)$ \\
\hline 23 & $0.1 \% \mathrm{Ti} / 0.1 \% \mathrm{Ca} / 0.1 \% \mathrm{Ti}\left(1400^{\circ} \mathrm{C}\right)$ \\
\hline 24 & $0.2 \% \mathrm{Ti} / 0.1 \% \mathrm{Ca}\left(1400^{\circ} \mathrm{C}\right)$ \\
\hline 25 & $0.3 \% \mathrm{Ti} / 0.02 \% \mathrm{Ca}\left(1400^{\circ} \mathrm{C}\right)$ \\
\hline 26 & $0.005 \% \mathrm{O} / 0.3 \% \mathrm{Ti} / 0.002 \% \mathrm{O} / 0.1 \% \mathrm{Ca}\left(1400^{\circ} \mathrm{C}\right)$ \\
\hline \multirow[t]{2}{*}{27} & $0.005 \% \mathrm{O} / 0.3 \% \mathrm{Ti} / 0.1 \% \mathrm{Ca}\left(1400^{\circ} \mathrm{C}\right)$ \\
\hline & $\mathrm{Al} / \mathrm{Ti} / \mathrm{Ca}$ \\
\hline $28 *$ & $0.05 \% \mathrm{Al} / 0.3 \% \mathrm{Ti} / 0.1 \% \mathrm{Ca}\left(1400^{\circ} \mathrm{C}\right)$ \\
\hline $29 *$ & $0.02 \% \mathrm{Al} / 0.3 \% \mathrm{Ti} / 0.1 \% \mathrm{Ca}\left(1400^{\circ} \mathrm{C}\right)$ \\
\hline $30 *$ & $0.05 \% \mathrm{Al} / 0.3 \% \mathrm{Ti} / 0.003 \% \mathrm{O} / 0.075 \% \mathrm{Ca}\left(1400^{\circ} \mathrm{C}\right)$ \\
\hline 31 & $0.003 \% \mathrm{Al} / 0.2 \% \mathrm{Ti} / 0.1 \% \mathrm{Ca}\left(450^{\circ} \mathrm{C}\right)$ \\
\hline \multirow[t]{2}{*}{32} & $0.003 \% \mathrm{Al} / 0.2 \% \mathrm{Ti} / 0.1 \% \mathrm{Ca}\left(450^{\circ} \mathrm{C}\right)$ \\
\hline & $\mathrm{Ti} / \mathrm{Al} / \mathrm{Ca}$ \\
\hline 33 & $0.25 \% \mathrm{Ti} / 0.05 \% \mathrm{Al} / 0.1 \% \mathrm{Ca}\left(1400^{\circ} \mathrm{C}\right)$ \\
\hline $34 *$ & $\begin{array}{l}0.003 \% \mathrm{O} / 0.25 \% \mathrm{Ti} / 0.05 \% \mathrm{Al} / 0.1 \% \mathrm{Ca}-1540^{\circ} \mathrm{C}, 10 \mathrm{~min} \\
\left(1400^{\circ} \mathrm{C}\right)\end{array}$ \\
\hline $35 *$ & $\begin{array}{l}0.003 \% \mathrm{O} / 0.35 \% \mathrm{Ti} / 0.05 \% \mathrm{Al} / 0.1 \% \mathrm{Ca}-1540^{\circ} \mathrm{C}, 10 \mathrm{~min} \\
\left(1400^{\circ} \mathrm{C}\right)\end{array}$ \\
\hline $36 *$ & $0.003 \% \mathrm{O} / 0.25 \% \mathrm{Ti} / 0.05 \% \mathrm{Al} / 0.1 \% \mathrm{Ca}\left(1400^{\circ} \mathrm{C}\right)$ \\
\hline \multirow[t]{2}{*}{$37 *$} & $0.003 \% \mathrm{O} / 0.35 \% \mathrm{Ti} / 0.05 \% \mathrm{Al} / 0.1 \% \mathrm{Ca}\left(1400^{\circ} \mathrm{C}\right)$ \\
\hline & $\mathrm{Ti} / \mathrm{Ca} / \mathrm{Al}$ \\
\hline $38 *$ & $\begin{array}{l}0.003 \% \mathrm{O} / 0.25 \% \mathrm{Ti} / 0.1 \% \mathrm{Ca} / 0.05 \% \mathrm{Al}-1540^{\circ} \mathrm{C}, 10 \mathrm{~min} \\
\left(1400^{\circ} \mathrm{C}\right)\end{array}$ \\
\hline \multirow[t]{2}{*}{$39 *$} & $0.003 \% \mathrm{O} / 0.25 \% \mathrm{Ti} / 0.1 \% \mathrm{Ca} / 0.05 \% \mathrm{Al}\left(1400^{\circ} \mathrm{C}\right)$ \\
\hline & $\mathrm{Ti} / \mathrm{Al} / \mathrm{Ca}$ \\
\hline $40 * \mathrm{M}$ & $0.25 \% \mathrm{Ti} / 0.05 \% \mathrm{Al} / 0.1 \% \mathrm{Ca}\left(1400^{\circ} \mathrm{C}\right)$ \\
\hline $41 * \mathrm{M}$ & $0.25 \% \mathrm{Ti} / 0.025 \% \mathrm{Al} / 0.1 \% \mathrm{Ca} / 0.025 \% \mathrm{Al}\left(1400^{\circ} \mathrm{C}\right)$ \\
\hline \multirow[t]{2}{*}{$42 * \mathrm{M}$} & $0.25 \% \mathrm{Ti} / 0.1 \% \mathrm{Ca} / 0.05 \% \mathrm{Al}\left(1400^{\circ} \mathrm{C}\right)$ \\
\hline & $\mathrm{Ti} / \mathrm{Mg} / \mathrm{Ca}$ \\
\hline $43 *$ & $0.15 \% \mathrm{Ti} / 0.1 \% \mathrm{Mg} / 0.15 \% \mathrm{Ti} / 0.1 \% \mathrm{Ca}\left(1450^{\circ} \mathrm{C}\right)$ \\
\hline $44 *$ & $0.3 \% \mathrm{Ti} / 0.1 \% \mathrm{Mg} / 0.1 \% \mathrm{Ca}\left(1400^{\circ} \mathrm{C}\right)$ \\
\hline $45 *$ & $0.15 \% \mathrm{Ti} / 0.1 \% \mathrm{Mg} / 0.15 \% \mathrm{Ti} / 0.1 \% \mathrm{Ca}\left(1400^{\circ} \mathrm{C}\right)$ \\
\hline $46 *$ & $\begin{array}{l}0.15 \% \mathrm{Ti} / 0.1 \% \mathrm{Mg} / 0.15 \% \mathrm{Ti} / 0.1 \% \mathrm{Ca}-1600^{\circ} \mathrm{C}, 10 \mathrm{~min} \\
\left(1400^{\circ} \mathrm{C}\right)\end{array}$ \\
\hline 47 & $0.3 \% \mathrm{Ti} / 0.1 \% \mathrm{Mg} / 0.1 \% \mathrm{Ca}\left(1400^{\circ} \mathrm{C}\right)$ \\
\hline 48 & $0.3 \% \mathrm{Ti} / 0.1 \% \mathrm{Ca} / 0.1 \% \mathrm{Mg}\left(1400^{\circ} \mathrm{C}\right)$ \\
\hline \multirow[t]{2}{*}{49} & $\begin{array}{l}0.15 \% \mathrm{Ti} / 0.1 \% \mathrm{Mg} / 0.15 \% \mathrm{Ti} / 0.1 \% \mathrm{Ca}-1600^{\circ} \mathrm{C}, 10 \mathrm{~min} \\
\left(1400^{\circ} \mathrm{C}\right)\end{array}$ \\
\hline & $\mathrm{Ti} / \mathrm{Zr}$ \\
\hline 50 & $0.3 \% \mathrm{Ti} / 0.05 \% \mathrm{Zr}\left(1400^{\circ} \mathrm{C}\right)$ \\
\hline 51 & $0.2 \% \mathrm{Ti} / 0.05 \% \mathrm{Zr}\left(450^{\circ} \mathrm{C}\right)$ \\
\hline $52 *$ & $0.2 \% \mathrm{Ti} / 0.05 \% \mathrm{Zr}\left(450^{\circ} \mathrm{C}\right)$ \\
\hline \multirow[t]{2}{*}{53} & $0.2 \% \mathrm{Ti} / 0.05 \% \mathrm{Zr}\left(1400^{\circ} \mathrm{C}\right)$ \\
\hline & $\mathrm{Ti} / \mathrm{Ce}$ \\
\hline \multirow[t]{2}{*}{54} & $0.2 \% \mathrm{Ti} / 0.06 \% \mathrm{Ce}\left(1400^{\circ} \mathrm{C}\right)$ \\
\hline & $\mathrm{Ti} / \mathrm{Zr} / \mathrm{Mg}$ \\
\hline \multirow[t]{2}{*}{55} & $0.3 \% \mathrm{Ti} / 0.05 \% \mathrm{Zr} / 0.1 \% \mathrm{Mg}\left(1400^{\circ} \mathrm{C}\right)$ \\
\hline & $\mathrm{Ti} / \mathrm{Zr} / \mathrm{Ca}$ \\
\hline 56 & $0.3 \% \mathrm{Ti} / 0.05 \% \mathrm{Zr} / 0.1 \% \mathrm{Ca}\left(1400^{\circ} \mathrm{C}\right)$ \\
\hline \multirow[t]{2}{*}{$57 *$} & $0.003 \% \mathrm{O} / 0.25 \% \mathrm{Ti} / 0.05 \% \mathrm{Zr} / 0.1 \% \mathrm{Ca}\left(1400^{\circ} \mathrm{C}\right)$ \\
\hline & $\mathrm{Ti} / \mathrm{Ce} / \mathrm{Ca}$ \\
\hline 58 & $0.2 \% \mathrm{Ti} / 0.06 \% \mathrm{Ce} / 0.1 \% \mathrm{Ca}\left(1400^{\circ} \mathrm{C}\right)$ \\
\hline \multirow[t]{2}{*}{$59 *$} & $0.003 \% \mathrm{O} / 0.25 \% \mathrm{Ti} / 0.05 \% \mathrm{Ce} / 0.1 \% \mathrm{Ca}\left(1400^{\circ} \mathrm{C}\right)$ \\
\hline & $\mathrm{Al} / \mathrm{Ti} / \mathrm{Ca}$ \\
\hline $60 * \mathrm{M}$ & $0.05 \% \mathrm{Al} / 0.3 \% \mathrm{Ti} / 0.1 \% \mathrm{Ca}\left(1400^{\circ} \mathrm{C}\right)$ \\
\hline $61 * \mathrm{M}$ & $0.02 \% \mathrm{Al} / 0.3 \% \mathrm{Ti} / 0.1 \% \mathrm{Ca}\left(1400^{\circ} \mathrm{C}\right)$ \\
\hline $\begin{array}{l}*: 17.5 \% \mathrm{C} \\
\mathrm{M}: \mathrm{MgO} \mathrm{cr}\end{array}$ & $\begin{array}{ll}\mathrm{Cr} & \text { without } *: 11 \% \mathrm{Cr} \\
\text { crucible } & \text { without } \mathrm{M}: \mathrm{Al}_{2} \mathrm{O}_{3} \text { crucible }\end{array}$ \\
\hline
\end{tabular}


Table 2. Deoxidation experiments with slag.

\begin{tabular}{|c|c|c|}
\hline \multicolumn{2}{|c|}{ Exp.No. } & \multirow[t]{2}{*}{ Deoxidant } \\
\hline & & \\
\hline SM-1 & & $0.05 \% \mathrm{Al} / 0.3 \% \mathrm{Ti} / 0.1 \% \mathrm{Ca}, \operatorname{slag} \mathrm{A}-5 \min \left(1400^{\circ} \mathrm{C}\right)$ \\
\hline \multirow{2}{*}{\multicolumn{2}{|c|}{2}} & $0.02 \% \mathrm{Al} / 0.3 \% \mathrm{Ti} / 0.1 \% \mathrm{Ca}, \operatorname{slag} \mathrm{A}-5 \min \left(1400^{\circ} \mathrm{C}\right)$ \\
\hline & & $\mathrm{Ti} / \mathrm{Al} / \mathrm{Ca}$ \\
\hline 3 & & $0.3 \% \mathrm{Ti} / 0.05 \% \mathrm{Al} / 0.1 \% \mathrm{Ca}, \mathrm{slagB}-5 \min \left(1400^{\circ} \mathrm{C}\right)$ \\
\hline \multirow{2}{*}{\multicolumn{2}{|c|}{4}} & $0.3 \% \mathrm{Ti} / 0.02 \% \mathrm{Al} / 0.1 \% \mathrm{Ca}, \operatorname{slagB}-5 \min \left(1400^{\circ} \mathrm{C}\right)$ \\
\hline & & $\mathrm{Al} / \mathrm{Ti} / \mathrm{Ca}$ \\
\hline \multirow[t]{2}{*}{5} & M & $0.05 \% \mathrm{Al} / 0.3 \% \mathrm{Ti} / 0.1 \% \mathrm{Ca}, \operatorname{slagA}-5 \min \left(1400^{\circ} \mathrm{C}\right)$ \\
\hline & & $\mathrm{Ti} / \mathrm{Al} / \mathrm{Ca}$ \\
\hline \multirow[t]{2}{*}{6} & M & $0.3 \% \mathrm{Ti} / 0.05 \% \mathrm{Al} / 0.1 \% \mathrm{Ca}, \operatorname{slag} \mathrm{A}-5 \min \left(1400^{\circ} \mathrm{C}\right)$ \\
\hline & & $\mathrm{Al} / \mathrm{Ti} / \mathrm{Ca}$ \\
\hline \multirow[t]{2}{*}{7} & $\mathrm{~A}+\mathrm{M}$ & $0.05 \% \mathrm{Al} / 0.3 \% \mathrm{Ti} / 0.1 \% \mathrm{Ca}, \operatorname{slag} \mathrm{A}-5 \min \left(1400^{\circ} \mathrm{C}\right)$ \\
\hline & & $\mathrm{Ti} / \mathrm{Al} / \mathrm{Ca}$ \\
\hline \multirow[t]{2}{*}{8} & $\mathrm{~A}+\mathrm{M}$ & $0.3 \% \mathrm{Ti} / 0.05 \% \mathrm{Al} / 0.1 \% \mathrm{Ca}, \operatorname{slag} \mathrm{A}-5 \min \left(1400^{\circ} \mathrm{C}\right)$ \\
\hline & & $\mathrm{Al} / \mathrm{Ti} / \mathrm{Ca}$ \\
\hline 9 & $\mathrm{~A}+\mathrm{M}$ & $0.1 \% \mathrm{Al} / 0.3 \% \mathrm{Ti} / 0.1 \% \mathrm{Ca}, \operatorname{slagA}-5 \min \left(1400^{\circ} \mathrm{C}\right)$ \\
\hline 10 & $\mathrm{~A}+\mathrm{M}$ & $0.05 \% \mathrm{Al} / 0.3 \% \mathrm{Ti} / 0.1 \% \mathrm{Ca}, \operatorname{slag} \mathrm{A}-15 \min \left(1400^{\circ} \mathrm{C}\right)$ \\
\hline
\end{tabular}

$\mathrm{M}: \mathrm{MgO}$ crucible

$\mathrm{A}+\mathrm{M}: \mathrm{Al}_{2} \mathrm{O}_{3}$ crucible with $\mathrm{MgO}$-ring

without $\mathrm{M}$ and $\mathrm{A}+\mathrm{M}: \mathrm{Al}_{2} \mathrm{O}_{3}$ crucible

SlagA: $56 \% \mathrm{CaO}-39 \% \mathrm{Al}_{2} \mathrm{O}_{3}-5 \% \mathrm{MgO}$

SlagB: $31 \% \mathrm{CaO}-65 \% \mathrm{Al}_{2} \mathrm{O}_{3}-4 \% \mathrm{MgO}$

and 59, the initial $\mathrm{O}$ and $\mathrm{N}$ contents were increased by the addition of an $\mathrm{Fe}-0.12 \% \mathrm{O}$ alloy and an $\mathrm{Fe}-6.3 \% \mathrm{~N}$ mixture, respectively, to increase the number of $\mathrm{TiN}$, complex TiN+oxide and oxide particles. In Exps. 26 and 30, an Fe$0.12 \% \mathrm{O}$ alloy was added during the intermediate deoxidation period to bring about an increase in the number of oxide particles. In Exps. 2, 3, 6, 7, 31, 32, 51 and 52, the samples were cooled to $450^{\circ} \mathrm{C}$ to study the effect of TiN precipitation during cooling. In Exps. 14 and 43, these melts were cooled to 1200 and $1450^{\circ} \mathrm{C}$, respectively, followed by quenching. In Exps. 46 and 49 , the melt was held for $10 \mathrm{~min}$ at $1600^{\circ} \mathrm{C}$ after the addition of $\mathrm{Ca}$, followed by cooling to bring about a decrease in the number of particles and an increase in the particle size.

Experiments on deoxidation in the presence of a slag phase were carried out to study the effect of slag composition on the solidification structure as functions of Al content, order of deoxidants addition, crucible materials and holding time at $1600^{\circ} \mathrm{C}$. The deoxidation methods using two types of slag $(20 \mathrm{~g})$ are given in Table 2 . After holding for $5 \mathrm{~min}$, the melt was cooled to $1400^{\circ} \mathrm{C}$ at a rate of $5^{\circ} \mathrm{C} / \mathrm{min}$. A MgO-ring was installed in an $\mathrm{Al}_{2} \mathrm{O}_{3}$ crucible, which floated on the metal during the deoxidation experiment, which is denoted as " $\mathrm{A}+\mathrm{M}$ ".

\subsection{Inclusion Analysis}

2.2.1. Planar Size, Number and Composition

The planar size distribution of particles (TiN, complex and oxide) above $1.5 \mu \mathrm{m}$ in a polished cross section of each sample was observed using an optical microscope at a magnification of 500. The total observation area of one sample was 0.5 to $2 \mathrm{~mm}^{2}$, which corresponds to 24 observation areas consisting of six continuous observation areas in the horizontal direction and four continuous observation areas in the vertical direction in the top, middle and bottom parts of a sliced ingot. The maximum length of the particle, $l_{\max }$, was measured and this length represents the planar size in this study.

\subsubsection{Spatial Size, Number and Composition}

Characteristics such as number, size and composition of spatial particles were analyzed on the surface of a polycar- bonate membrane filter with an open pore size of $0.05 \mu \mathrm{m}$ after potentiostatic electrolytic extraction $(150 \mathrm{mV}, 45$ to 55 $\mathrm{mA} / \mathrm{cm}^{2}$ and 300 to 600 coulomb) and filtration. Metal samples were dissolved with $10 \%$ AA ( $10 \mathrm{v} / \mathrm{v} \%$ acetylaceton-1 $\mathrm{w} / \mathrm{v} \%$ tetramethylammonium chloride-methanol) in Ti- and $\mathrm{Zr}$-added deoxidation experiments and with 2\% TEA ( $2 \mathrm{v} / \mathrm{v} \%$ triethanolamine-1 $\mathrm{w} / \mathrm{v} \%$ tetramethylammonium chloridemethanol) in $\mathrm{Mg}$ - and $\mathrm{Ce}$-added deoxidation experiments. The weight of the dissolved metal was 0.15 to $0.25 \mathrm{~g}$. After extraction, particles on the film filter were observed and analyzed by field emission SEM-EDX at magnifications of 1000 and 5000 . The total observed area on a film filter was 0.11 to $0.13 \mathrm{~mm}^{2}$ at 1000 magnification and 0.002 to 0.0005 $\mathrm{mm}^{2}$ at 5000 magnification. The spatial size, $d \mathrm{v}$, of each particle in the SEM image was estimated using a semi-automatic image analyzer.

\subsection{Solidification Structure}

The solidification structure was observed on a cross section of an ingot sample. A vertically sliced sample from the centre of ingot was polished and etched with aqua resia ( $\mathrm{HCl}: \mathrm{HNO}_{3}=3: 1$ by volume).

\section{Results and Discussion}

\subsection{Complex Deoxidation for TiN Crystallization}

The size and number of the complex particles are determined from the content of $\mathrm{Ti}$ and $\mathrm{N}$, the size, number and surface composition of oxide particles and the cooling rate. In this study, the total $\mathrm{O}$ and $\mathrm{N}$ contents were 43 to $200 \mathrm{ppm}$ and 18 to $401 \mathrm{ppm}$, respectively and the Ti content was 0.2 to $0.3 \%$.

Although $\mathrm{Ti}_{3} \mathrm{O}_{5}$ is the equilibrium phase in a melt and $\mathrm{Ti}_{2} \mathrm{O}_{3}$ is that in a solid, the notation of $\mathrm{TiO}_{x}$ is used for titanium oxide of both melt and solid in this study.

For the purpose of comparison, only $\mathrm{Ti}$ deoxidation (Exps. 1 through 4) and $\mathrm{Al}$ deoxidation, followed by $\mathrm{Ti}$ addition after $30 \mathrm{~min}$ (Exp. 5) using an $\mathrm{Al}_{2} \mathrm{O}_{3}$ crucible were carried out at total $\mathrm{N}=70$ to 335 and total $\mathrm{O}=51$ to $200 \mathrm{ppm}$. The TiN, complex and oxide particles above $1.5 \mu \mathrm{m}$ were observed and these particles were found to be clustered except in Exp. 1 because of the high $\mathrm{N}$ and $\mathrm{O}$ contents. The complex deoxidation method is classified according to the composition of deoxidation particles as follows:

(1) $\mathrm{MgO}-\mathrm{Al}_{2} \mathrm{O}_{3}-\mathrm{TiO}_{x}$ system: In $\mathrm{Mg}$ deoxidation (Exps. 6 and 7) using an $\mathrm{Al}_{2} \mathrm{O}_{3}$ crucible, $\mathrm{MgO}$ and $\mathrm{MgO}-$ $\mathrm{Al}_{2} \mathrm{O}_{3}$ particles are produced depending on the yield of $\mathrm{Mg}$ addition. If the $\mathrm{Mg}$ addition is insufficient owing to low $\mathrm{Mg}$ yield, a non-equilibrium phase of the $\mathrm{MgO}-\mathrm{FeO}$ system is produced. ${ }^{8)} \mathrm{In} \mathrm{Ti} / \mathrm{Mg}$ deoxidation (Exps. 9 and 10) using a $\mathrm{MgO}$ crucible and (Exps. 8 and 11 through 18) an $\mathrm{Al}_{2} \mathrm{O}_{3}$ crucible, particles with $\mathrm{TiO}_{x}-\mathrm{MgO}$ (Exps. 9 and 10), $\mathrm{MgO}-$ $\mathrm{Al}_{2} \mathrm{O}_{3}-\mathrm{TiO}_{x}$ (Exps. 14 and 16) and $\mathrm{MgO}-\mathrm{Al}_{2} \mathrm{O}_{3}$ (Exps. 8 and 11) systems were observed. In $\mathrm{Al} / \mathrm{Mg} / \mathrm{Ti}$ (Exp. 19) and $\mathrm{Ti} /$ $\mathrm{Mg} / \mathrm{Al}$ (Exp. 20) deoxidation using an $\mathrm{Al}_{2} \mathrm{O}_{3}$ crucible, the formation of particles with a $\mathrm{MgO}-\mathrm{Al}_{2} \mathrm{O}_{3}-\mathrm{TiO}_{x}$ system was observed.

(2) $\mathrm{CaO}-\mathrm{Al}_{2} \mathrm{O}_{3}-\mathrm{TiO}_{x}$ system: In $\mathrm{Ti} / \mathrm{Ca}$ deoxidations (Exps. 21 through 27) using an $\mathrm{Al}_{2} \mathrm{O}_{3}$ crucible, $\mathrm{CaO}-\mathrm{Al}_{2} \mathrm{O}_{3}-$ $\mathrm{TiO}_{x}$ particles were observed and the $\mathrm{TiO}_{x}$ content depended on the $\mathrm{Ca}$ addition yield. In $\mathrm{Al} / \mathrm{Ti} / \mathrm{Ca}$ (Exps. 28 through 32), $\mathrm{Ti} / \mathrm{Al} / \mathrm{Ca}$ (Exps. 33 through 37) and Ti/Ca/Al (Exps. 38 and 39) deoxidations using an $\mathrm{Al}_{2} \mathrm{O}_{3}$ crucible, particles with the $\mathrm{CaO}-\mathrm{Al}_{2} \mathrm{O}_{3}-\mathrm{TiO}_{x}$ system were observed.

(3) $\mathrm{TiO}_{x}-\mathrm{CaO}-\mathrm{MgO}-\mathrm{Al}_{2} \mathrm{O}_{3}$ system: In $\mathrm{Ti} / \mathrm{Al} / \mathrm{Ca}$ (Exps. 40 through 42) and $\mathrm{Al} / \mathrm{Ti} / \mathrm{Ca}$ (Exps. 60 and 61) deoxidations using a $\mathrm{MgO}$ crucible, particles with the $\mathrm{TiO}_{x}-\mathrm{CaO}-\mathrm{MgO}-$ $\mathrm{Al}_{2} \mathrm{O}_{3}$ system were observed. Due to low $\mathrm{MgO}$ content $(<6 \%)$, which depends on the soluble Al content with the 
exception of Exp. 42, $\mathrm{MgO} \cdot \mathrm{Al}_{2} \mathrm{O}_{3}-2 \mathrm{MgO} \cdot \mathrm{TiO}_{2}$ solid solution was not crystallized.

In $\mathrm{Ti} / \mathrm{Mg} / \mathrm{Ca}$ (Exps. 44 and 47), $\mathrm{Ti} / \mathrm{Ca} / \mathrm{Mg}$ (Exp. 48) and $\mathrm{Ti} / \mathrm{Mg} / \mathrm{Ti} / \mathrm{Ca}$ (Exps. 43, 45, 46 and 49) deoxidations using an $\mathrm{Al}_{2} \mathrm{O}_{3}$ crucible, particles with $\mathrm{CaO}-\mathrm{MgO}-\mathrm{TiO}_{x}$ (Exp. 47), $\mathrm{MgO}-\mathrm{Al}_{2} \mathrm{O}_{3}-\mathrm{TiO}_{x}$ (Exps. 43, 45, 46 and 49) and $\mathrm{CaO}-$ $\mathrm{MgO}-\mathrm{Al}_{2} \mathrm{O}_{3}$ (Exps. 44 and 48) systems were observed, irrespective of the order of deoxidant addition. In $\mathrm{Al} / \mathrm{Ti} / \mathrm{Ca}$ (Exps. SM-1, SM-5 and SM-7) and Ti/Ca/Al (Exps. SM-6 and $\mathrm{SM}-8$ ) deoxidations in the presence of $\mathrm{CaO}-\mathrm{MgO}-$ $\mathrm{Al}_{2} \mathrm{O}_{3}$ slags, $\mathrm{MgO} \cdot \mathrm{Al}_{2} \mathrm{O}_{3}-2 \mathrm{MgO} \cdot \mathrm{TiO}_{2}$ solid solution was crystallized from $\mathrm{TiO}_{x}-\mathrm{CaO}-\mathrm{Al}_{2} \mathrm{O}_{3}-\mathrm{MgO}$ liquid particles except in Exp. SM-1.

(4) Other systems containing $\mathrm{ZrO}_{2}$ and $\mathrm{Ce}_{2} \mathrm{O}_{3}$ phases: In Ti/Zr (Exps. 50 through 53), Ti/Ce (Exps. 54 and 55), Ti/Zr/ $\mathrm{Ca}$ (Exps. 56 and 57) and Ti/Ce/Ca (Exps. 58 and 59) deoxidations using an $\mathrm{Al}_{2} \mathrm{O}_{3}$ crucible, particles consisted of complex phases with compositions containing $\mathrm{TiO}_{x}, \mathrm{Al}_{2} \mathrm{O}_{3}$, $\mathrm{ZrO}_{2}, \mathrm{Ce}_{2} \mathrm{O}_{3}$ and $\mathrm{CaO}$.

A more detailed description of particle compositions is given in a separate paper. ${ }^{\text {) }}$

\subsection{Characteristics of Planar and Spatial Size Distri- bution}

The size distributions of TiN, complex and oxide particles were measured using an optical microscope and these particles are easily distinguished from their morphologies; TiN and complex particles are cuboidal and oxide particles are irregular or spherical. However, the separation of TiN and complex particles is difficult in the case where TiN crystallizes on fine oxide particle. In this study the maximum length of the particles, $l_{\max }$, represents the particle size, because the shape of the particles except for that of oxide particles was not circular. This method is denoted as the 2$\mathrm{D}$ method, hereafter. The planar size distributions in the range above $l_{\max }=1.5 \mu \mathrm{m}$ are shown in Fig. 1, in which the results for $\mathrm{Ti} / \mathrm{Al} / \mathrm{Ca}$ (Exp. 40), Ti/Ca/Al (Exp. 38), Ti/Mg/ $\mathrm{Ca}$ (Exp. 43) and Ti/Ca/Mg (Exp. 48) deoxidations are given

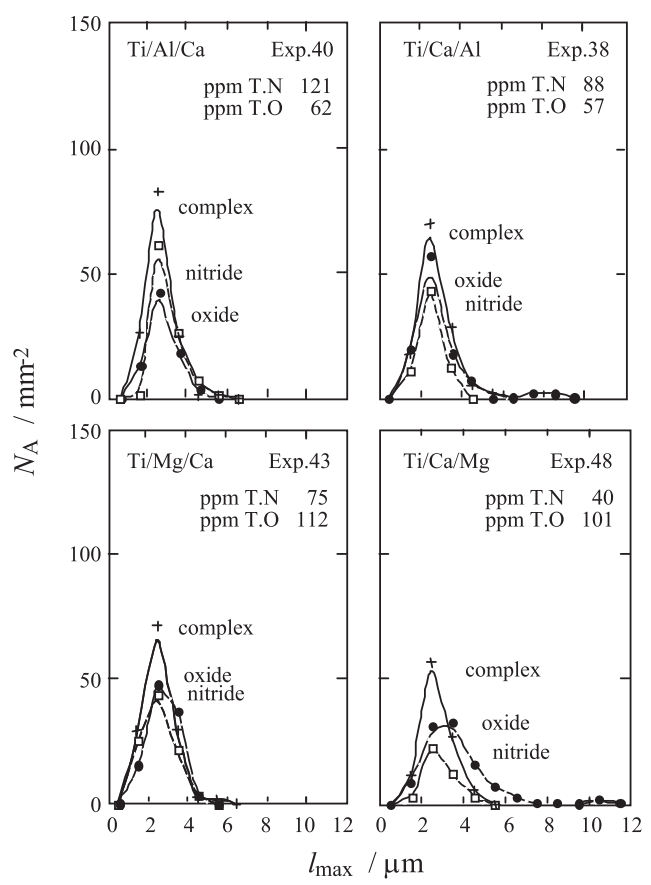

Fig. 1. Planar size distributions of complex TiN+oxide, TiN, and oxide particles in $\mathrm{Ti} / \mathrm{Al} / \mathrm{Ca}(\operatorname{Exp} .40), \mathrm{Ti} / \mathrm{Ca} / \mathrm{Al}$ (Exp.38), Ti/ $\mathrm{Mg} / \mathrm{Ca}$ (Exp.43), and $\mathrm{Ti} / \mathrm{Ca} / \mathrm{Mg}$ (Exp.48) deoxidation experiments. as typical example, of the 2-D method. It can be seen that the size distributions of respective particles are nearly the same. Most of curves are characterized by a modal value of around $3 \mu \mathrm{m}$, and the curve on the left-hand side approaches zero at around $1 \mu \mathrm{m}$, because the minimum size of the respective particles measured by the $2-\mathrm{D}$ method is $1.5 \mu \mathrm{m}$. Although the particle size above $0.5 \mu \mathrm{m}$ can be estimated for the particles on a cross section by using scanning electron microscopy (SEM) with an electron probe microanalyzer (EPMA), ${ }^{9)}$ the composition of the crystallized phase in particles below $1 \mu \mathrm{m}$ is difficult to measure accurately.

In the 2-D method, the morphology of particles on a cross section can be measured for TiN, complex and oxide particles, although the separation of TiN and complex particles is difficult in the case where TiN crystallizes on small oxide particles. The merit of the 2-D method is the ability to analyze the chemical compositions of the complex particles consisting of various phases in matrix and TiN layers by using SEM with EPMA. However, the drawback of using an optical microscope, rather than SEM with EPMA is that the number of particles below $1.5 \mu \mathrm{m}$ cannot be estimated.

The spatial size distribution of particles in the $\mathrm{Ti} / \mathrm{Al} / \mathrm{Ca}$ $(\mathrm{MgO})$ deoxidation (Exp. 40) is shown in Fig. 2, where $\Delta \log$ $d_{\mathrm{v}}=0.1$ was chosen in this study so that the trend of the curves may not change. The measurement of particles on a film filter by the electrolytic extraction method is denoted as the 3-D method, hereafter. The size distribution of total particles shows a bimodal curve, as shown in the top diagram. The results were obtained by using a film filter with a pore size of $0.1 \mu \mathrm{m}$ and at 5000 magnification using SEM with EPMA. It is pointed out that film filters with a pore size of $0.1(0.01$ and 0.05$) \mu \mathrm{m}$ and high magnifications such as 2500 and 5000 are necessary for the accurate measurement of small particles below $1 \mu \mathrm{m}$, whereas a film filter with a pore size of $1(0.5) \mu \mathrm{m}$ and low magnifications such as 500 and 1000 are necessary for the accurate measurement of large particles above $1 \mu \mathrm{m}$. It is possible to measure large particles by using a film filter with a pore size of 0.1

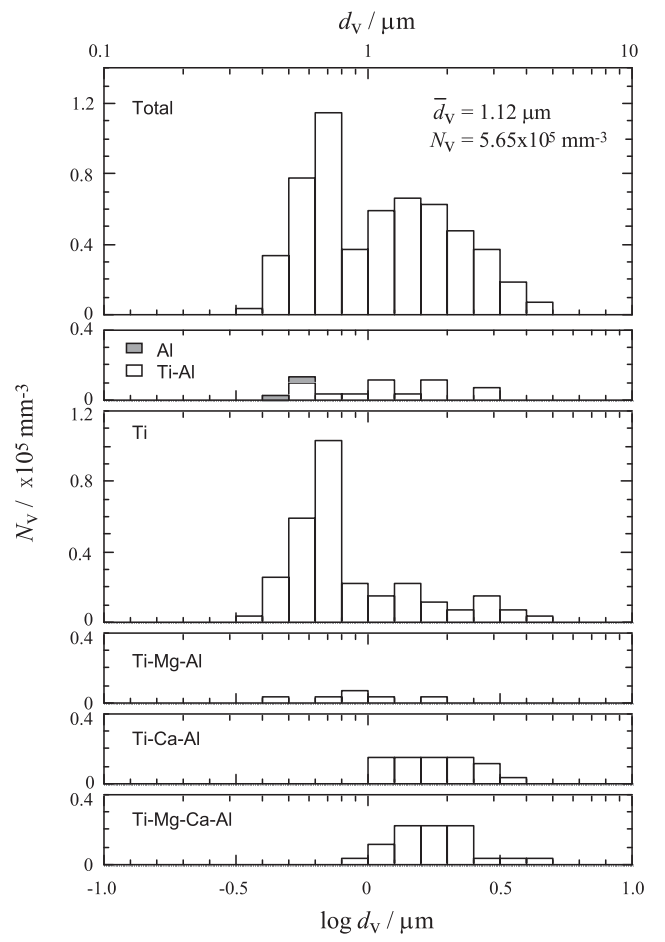

Fig. 2. Spatial size distributions of particles in $\mathrm{Ti} / \mathrm{Al} / \mathrm{Ca}(\mathrm{MgO}$ crucible) deoxidation experiment (Exp. 40) under 5000 magnification. 
$\mu \mathrm{m}$ coupled with a low magnification such as 500 and 1000 . In the measurement of large size particles, however, it is recommended that a film filter with a pore size of $1 \mu \mathrm{m}$ is used coupled with low magnification, because the filtering time is long and the amount of dissolved metal during electrolytic extraction is limited.

The size distribution of particles with varying compositions shown in Fig. 2 consists of different phases that are represented by notation of such as "Ti-Ca-Al". The merit of the 3-D method is that it is possible to measure small particles by using the proper conditions mentioned previously, but the drawback is not being able to separate TiN and complex particles from the particle morphology. Furthermore, complex particles consisting of thick, thin and partially crystallized TiN layers cannot be classified in the 3-D method. This is the major drawback in the study of crystallization and precipitation of complex particles.

The result of the 2-D method for $\mathrm{Ti} / \mathrm{Al} / \mathrm{Ca}(\mathrm{MgO})$ (Exp. 40) deoxidation, shown on the left-hand side of the upper diagram of Fig. 1 is compared with that of the 3-D method for $\mathrm{Ti} / \mathrm{Al} / \mathrm{Ca}(\mathrm{MgO}$ ) (Exp. 40) deoxidation ( $\mathrm{T} . \mathrm{O}=78$ and $\mathrm{T} . \mathrm{N}=102 \mathrm{ppm}$ ), shown in Fig. 2. It is considered that the ranges below and above $1 \mu \mathrm{m}$ in the curve of $\mathrm{Ti}$ shown in Fig. 2 corresponds to TiN particles precipitated after solidification and to TiN particles before solidification, respectively. The curve of nitride shown on the left-hand side of the upper diagram of Fig. 1 corresponds to the range above $1 \mu \mathrm{m}$ shown in the curve of Ti in Fig. 2, in which the primary $\mathrm{TiO}_{x}$ content is very low.

Based on the comparison of the total curve shown in the top diagram of Fig. 2 with three curves in Fig. 1 (upper lefthand side), the curve on the left-hand side of Fig. 2 corresponds primarily to the precipitated TiN particles and the peak on the right-hand side corresponds to the crystallized TiN, complex and oxide particles. The curve on the righthand side of the total curve in Fig. 2 is located in the range of 1 to $2 \mu \mathrm{m}$, which is less than the $l_{\max }$ values of $2-3 \mu \mathrm{m}$ in the three curves in Fig. 1. These results indicate that the TiN, complex and oxide particles below $1.5 \mu \mathrm{m}$, which cannot be measured by the 2-D method, must be taken into

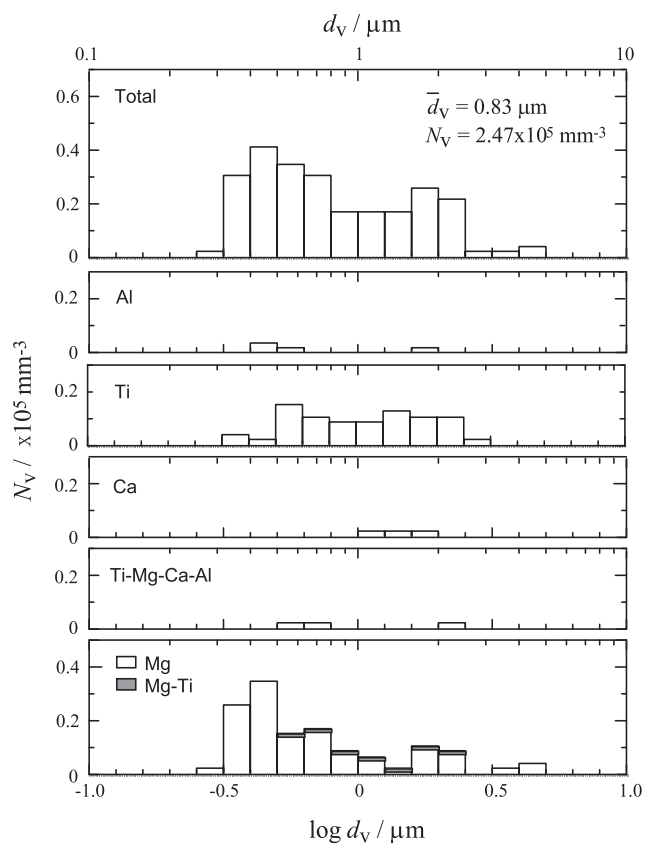

Fig. 3. Spatial size distributions of particles in $\mathrm{Ti} / \mathrm{Mg} / \mathrm{Ca}\left(\mathrm{Al}_{2} \mathrm{O}_{3}\right.$ crucible) deoxidation experiment in $\mathrm{Fe}-10 \% \mathrm{Ni}$ alloy under 5000 magnification. account. TiN and complex particles in the range between 1 and $2 \mu \mathrm{m}$ may contribute to the refining of the solidification structure, particularly, in the case of the particles with high nucleation potency for $\delta$-phase solidification. In the aforementioned discussion, planar particle size $\left(l_{\max }\right)$ is assumed to be equal to the spatial particle size $\left(d_{\mathrm{V}}\right)$.

\subsection{Crystallization and Precipitation Behavior of TiN}

In order to study the crystallization and precipitation behavior of $\mathrm{TiN}$, the experiments were carried out in an $\mathrm{Fe}-$ $10 \% \mathrm{Ni}$ alloy $(\mathrm{Ti}=0.30 \%, \mathrm{~N}=17 \mathrm{ppm}$ and $\mathrm{T} . \mathrm{O}=50 \mathrm{ppm})$ with $\mathrm{Ti} / \mathrm{Mg} / \mathrm{Ca}$ deoxidation and in an $\mathrm{Fe}-17.5 \% \mathrm{Cr}-0.25 \% \mathrm{Mn}-$ $0.20 \% \mathrm{Si}-0.01 \% \mathrm{C}$ alloy (Exp. $43: \mathrm{Ti}=0.30 \%, \mathrm{~N}=75 \mathrm{ppm}$ and $\mathrm{T} . \mathrm{O}=112 \mathrm{ppm}$ ) with $\mathrm{Ti} / \mathrm{Mg} / \mathrm{Ti} / \mathrm{Ca}$ deoxidation using an $\mathrm{Al}_{2} \mathrm{O}_{3}$ crucible. In the former deoxidation experiment with low $\mathrm{N}$ content, the behavior of the primary and secondary oxide particles can be clarified from the results of the particle size distribution. In the latter deoxidation experiment, the behavior of crystallized and precipitated TiN particles including complex particles can be clarified by comparing with the results obtained in the former deoxidation experiment. It is assumed that the size distributions of respective oxide particles after deoxidation show a similar trend in both deoxidation experiments. The reason for the use of an $\mathrm{Fe}-10 \% \mathrm{Ni}$ alloy in steady of using an $\mathrm{Fe}-\mathrm{Cr}$ alloy is to prepare an alloy containing low $\mathrm{N}$ content as much as possible, in which size distributions of only oxide particles are obtained. These results are shown in Figs. 3 and 4, respectively. As shown in Fig. 3, the size distribution of total particles shows a bimodal curve and the curve on the left-hand side corresponds to mostly primary deoxidation products of $\mathrm{MgO}$ and $\mathrm{MgO}-\mathrm{TiO}_{x}$ which are shown in the bottom diagram, together with the primary and secondary $\mathrm{TiO}_{x}$ particles. The range on the right-hand side corresponds to the primary deoxidation product of $\mathrm{TiO}_{x}$ particles and other primary oxides.

In a previous study, ${ }^{8}$ ) the bimodal size distribution was observed in $\mathrm{Ti} / \mathrm{Mg}$ deoxidation using an $\mathrm{Fe}-10 \% \mathrm{Ni}$ alloy, in which the size distributions of $\mathrm{TiO}_{x}, \mathrm{MgO}$ and $\mathrm{MgO}-\mathrm{TiO}_{x}$ particles were studied. These results are consistent with

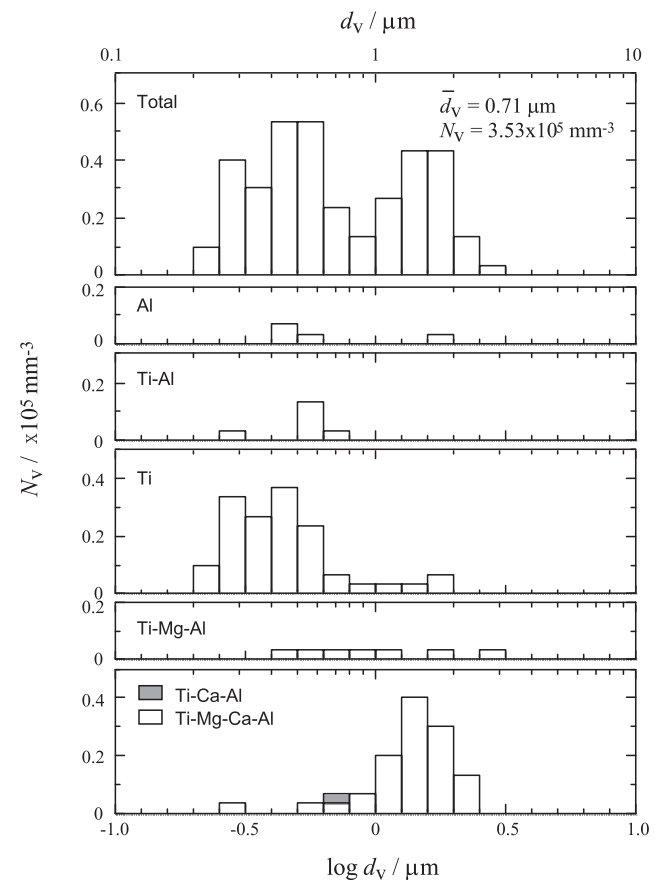

Fig. 4. Spatial size distributions of particles in $\mathrm{Ti} / \mathrm{Mg} / \mathrm{Ti} / \mathrm{Ca}\left(\mathrm{Al}_{2} \mathrm{O}_{3}\right.$ crucible) deoxidation experiment (Exp. 43) under 5000 magnification. 
those shown in Fig. 3. In $\mathrm{Ti} / \mathrm{Mg}$ deoxidation, $\mathrm{MgO}, \mathrm{MgO}-$ $\mathrm{TiO}_{x}$ and $\mathrm{TiO}_{x}$ particles are obtained depending upon the content of soluble $\mathrm{Mg}$, namely, the yield of $\mathrm{Mg}$ addition. If $\mathrm{Mg}$ yield is sufficiently high, primary $\mathrm{MgO}$ particles in addition to a small amount of primary $\mathrm{MgO}$-rich $\mathrm{TiO}_{x}$ particles are obtained, but no $\mathrm{TiO}_{x}$ particles are present because of complete reduction with $\mathrm{Mg}$. If $\mathrm{Mg}$ yield is low, which means that soluble $\mathrm{O}$ content is high, secondary $\mathrm{TiO}_{x}$ particles in addition to primary $\mathrm{TiO}_{x}$ particles and secondary $\mathrm{TiO}_{x}$-rich $\mathrm{MgO}$ particles are obtained. However, it is pointed that if oxygen is supersaturated even in the presence of $\mathrm{MgO}$ particles, the precipitation of $\mathrm{TiO}_{x}$ particles may occurs.

The crystallization and precipitation behavior of TiN can be discussed based on the size distributions shown in Fig. 4. As shown in the top diagram, the size distribution of total particles shows a bimodal curve and the curve on the lefthand side corresponds to the curve of $\mathrm{Ti}$, which consists of mostly precipitated $\mathrm{TiN}$ and $\mathrm{TiO}_{x}$ particles, as is clear from the curve of Ti. The curve on the right-hand side corresponds to mostly primary $\mathrm{Ti}-\mathrm{Mg}-\mathrm{Ca}-\mathrm{Al}$ oxide and crystallized complex particles, which are shown in the bottom diagram and a small amount of primary $\mathrm{TiO}_{x}$ particles. It is considered from the curve of $\mathrm{Ti}$ in an $\mathrm{Fe}-10 \% \mathrm{Ni}$ alloy, in which $\mathrm{N}$ content is low such as $17 \mathrm{ppm}$, that the curve of Ti shown in Fig. 4, in which $\mathrm{N}$ and Ti contents are $75 \mathrm{ppm}$ and $0.3 \%$, respectively, consists of primary and secondary $\mathrm{TiO}_{x}$ particles together with crystallized and precipitated TiN particles. However, it is expected from the equilibrium solubility product of $[\mathrm{Ti}] \cdot[\mathrm{N}]$ in an $\mathrm{Fe}-20 \% \mathrm{Cr}$ alloy ${ }^{7)}$ that the amount of crystallized $\mathrm{TiN}$ at $1520^{\circ} \mathrm{C}$ seems to be none. Therefore, there may be a large number of complex particles with a thin or partially precipitated TiN layer.

The reasons that small $\mathrm{MgO}$ particles observed in Fig. 3 are not present in the bottom diagram of Fig. 4 and large $\mathrm{Ti}-\mathrm{Mg}-$ $\mathrm{Ca}-\mathrm{Al}$ oxide particles observed in Fig. 4 are not present in the bottom diagram of Fig. 3 are attributed to the lower yield of $\mathrm{Mg}$ in Fig. 4 compared with that in Fig. 3. This different $\mathrm{Mg}$ yield arises from the fact that the solubility of $\mathrm{Mg}$ in an $\mathrm{Fe}-$ $10 \% \mathrm{Ni}$ alloy is significantly higher than that in an $\mathrm{Fe}-\mathrm{Cr}$ alloy.

Similar deoxidation experiments $(\mathrm{Ti} / \mathrm{Ca})$ to those in Figs. 3 and 4 were carried out so as to clarify the crystallization and precipitation behavior of TiN. These results are shown in Figs. 5 and 6. The spatial size distribution of $\mathrm{Ti} / \mathrm{Ca}$ deoxidation using an $\mathrm{Al}_{2} \mathrm{O}_{3}$ crucible in an $\mathrm{Fe}-10 \% \mathrm{Ni}$ alloy $(\mathrm{Ti}=0.30 \%, \mathrm{~N}=20 \mathrm{ppm}$ and $\mathrm{T} . \mathrm{O}=62 \mathrm{ppm})$ shown in Fig. 5 is

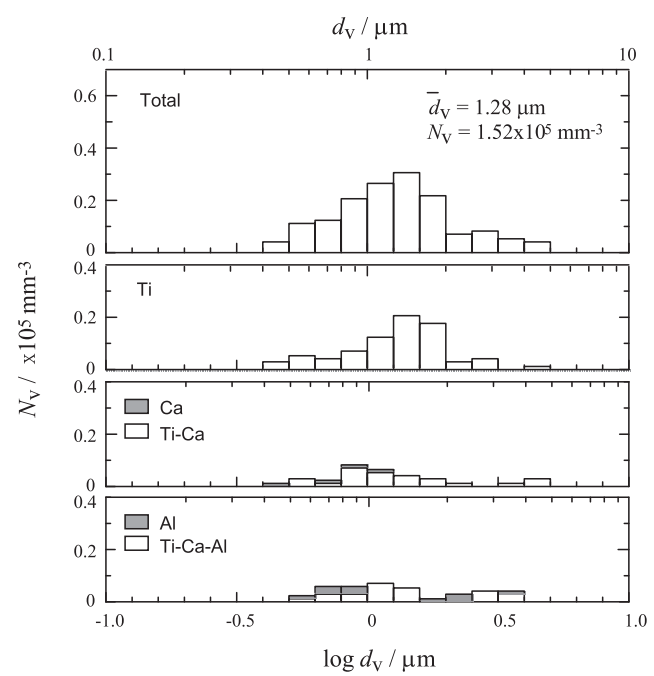

Fig. 5. Spatial size distributions of particles in $\mathrm{Ti} / \mathrm{Ca}\left(\mathrm{Al}_{2} \mathrm{O}_{3}\right.$ crucible) deoxidation experiment in $\mathrm{Fe}-10 \% \mathrm{Ni}$ alloy under 5000 magnification. used for explaining the behavior of primary and secondary oxide particles. The reason for choosing this deoxidation is that the modal value of the size distribution of oxide particles is larger than that in $\mathrm{Ti} / \mathrm{Mg} / \mathrm{Ca}$ deoxidation in Figs. 3 and 4. The spatial size distribution of $\mathrm{Al} / \mathrm{Ti} / \mathrm{Ca}$ deoxidation using a $\mathrm{MgO}$ crucible in an $\mathrm{Fe}-17.5 \% \mathrm{Cr}-0.25 \% \mathrm{Mn}-$ $0.20 \% \mathrm{Si}-0.01 \% \mathrm{C}$ alloy (Exp. $61: \mathrm{Ti}=0.30 \%, \mathrm{~N}=72 \mathrm{ppm}$ and T.O $=52$ ppm) shown in Fig. 6 is used for clarifying the crystallization and precipitation behavior of TiN by comparing with the results shown in Fig. 5. Although the conditions in both experiments are different with respect to the deoxidant addition $(\mathrm{Ti} / \mathrm{Ca}$ and $\mathrm{Al} / \mathrm{Ti} / \mathrm{Ca}$ ) and crucible material, it is assumed that these different conditions do not significantly affect the interpretation of the spatial size distributions, because alumina particles in cluster formed by the initial addition of $\mathrm{Al}$ float out immediately. For this reason, it is considered that the deoxidation system shown in Figs. 3 and 4 corresponds to $\mathrm{Ti} / \mathrm{Mg} / \mathrm{Ca}$ and that shown in Figs. 5 and 6 corresponds to $\mathrm{Ti} / \mathrm{Ca}$.

As shown in the top diagram of Fig. 5, the size distribution of total particles is not bimodal, but is instead a curve with single peak with a modal value of 1 to $2 \mu \mathrm{m}$. This result is different from that of the $\mathrm{Ti} / \mathrm{Mg} / \mathrm{Ca}$ deoxidation in an $\mathrm{Fe}-$ $10 \% \mathrm{Ni}$ alloy, shown in Fig. 3, in which small primary $\mathrm{MgO}$ and $\mathrm{MgO}-\mathrm{TiO}_{x}$ particles are present. Similarly, the size distribution of total particles in the $\mathrm{Al} / \mathrm{Ti} / \mathrm{Ca}$ deoxidation, shown in the top diagram of Fig. 6, shows a curve with a single peak with a modal value of 1 to $2 \mu \mathrm{m}$. This is different from the bimodal curve in $\mathrm{Ti} / \mathrm{Mg} / \mathrm{Ti} / \mathrm{Ca}$ deoxidation, shown in the top diagram of Fig. 4, in which the curve on the left-hand side corresponds to the precipitated TiN and mostly secondary $\mathrm{TiO}_{x}$ particles.

If the crystallization of TiN is suppressed under conditions in which the $[\mathrm{Ti}] \cdot[\mathrm{N}]$ product is high and the nucleation potency of particles is low, the precipitation of TiN is encouraged because of the high nucleation rate for TiN precipitation. This leads to a bimodal curve, which corresponds to the $\mathrm{Ti} /$ $\mathrm{Al} / \mathrm{Ca}(\mathrm{MgO})$ deoxidation $(\mathrm{N}=102 \mathrm{ppm})$, as shown in Fig. 2. On the other hand, if the crystallization of TiN on oxide particles is promoted under conditions in which the $[\mathrm{Ti}] \cdot[\mathrm{N}]$ sol-

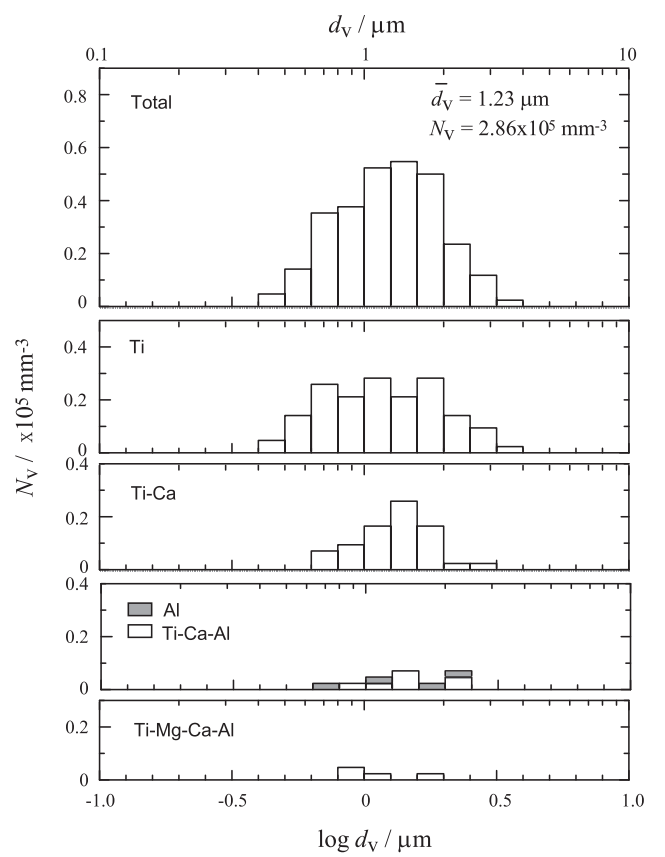

Fig. 6. Spatial size distributions of particles in $\mathrm{Al} / \mathrm{Ti} / \mathrm{Ca}(\mathrm{MgO}$ crucible) deoxidation experiment (Exp. 61) under 5000 magnification. 
ubility product is low and the nucleation potency is high, the precipitation of TiN on the complex oxide is encouraged. This leads to the curve with a single peak, which corresponds to the $\mathrm{Al} / \mathrm{Ti} / \mathrm{Ca}(\mathrm{MgO})$ deoxidation (72 ppm), as shown in Fig. 6 . The nucleation potency of oxide particles obtained in different deoxidations is discussed in a separate paper. ${ }^{6}$ )

\subsection{Variation of Particle Size Distribution during Cooling}

The variation of the particle size distribution during cooling is discussed as a function of nucleation potency, which is chosen from the following four different deoxidation methods: i) a large number of small particles with high nucleation potency $(\mathrm{Ti} / \mathrm{Mg}),{ }^{8,10)}$ ii) that with very low nucleation potency $(\mathrm{Ti} / \mathrm{Zr}),{ }^{8,10)}$ iii) a relatively large number of large particles with high nucleation potency $(\mathrm{Ti} / \mathrm{Mg} / \mathrm{Ca})$ and iv) a small number of large particles with low nucleation potency $(\mathrm{Ti} / \mathrm{Ca} /$ $\mathrm{Al}$ or $\mathrm{Ti} / \mathrm{Al} / \mathrm{Ca})$. The variation of the size distributions of these deoxidations during cooling are schematically illustrated in Fig. 7 for Ti/Mg and Ti/Zr deoxidations and Fig. 8 for $\mathrm{Ti} / \mathrm{Mg} / \mathrm{Ca}$ and $\mathrm{Ti} / \mathrm{Ca} / \mathrm{Al}$ or $\mathrm{Ti} / \mathrm{Al} / \mathrm{Ca}$ deoxidations. The crystallization and precipitation behavior of $\mathrm{TiN}$ in the presence of oxide particles is influenced by the $[\mathrm{Ti}] \cdot[\mathrm{N}]$ solubility product, nucleation potency of the surface composition of oxide particles and cooling rate. In the schematic illustration, it is assumed that the [Ti] $[\mathrm{N}]$ solubility product is chosen such that TiN crystallization occurs on the surface of $\mathrm{MgO}$, $\mathrm{MgO} \cdot \mathrm{Al}_{2} \mathrm{O}_{3}$ and $\mathrm{MgO} \cdot \mathrm{Al}_{2} \mathrm{O}_{3}-2 \mathrm{MgO} \cdot \mathrm{TiO}_{2}$ solid solutions. The nucleation potency for TiN crystallization decreases in the order of $\mathrm{MgO}>\mathrm{MgO} \cdot \mathrm{Al}_{2} \mathrm{O}_{3}>\mathrm{MgO} \cdot \mathrm{Al}_{2} \mathrm{O}_{3}-2 \mathrm{MgO} \cdot \mathrm{TiO}_{2}$ solid solutions $>$ oxide phases in the $\mathrm{CaO}-\mathrm{MgO}-\mathrm{TiO}_{x}$ system>oxide phases in the $\mathrm{CaO}-\mathrm{Al}_{2} \mathrm{O}_{3}-\mathrm{TiO}_{x}$ system in a $\mathrm{MgO}$ crucible $>$ oxide phases in the $\mathrm{CaO}-\mathrm{Al}_{2} \mathrm{O}_{3}-\mathrm{TiO}_{x}$ in an $\mathrm{Al}_{2} \mathrm{O}_{3}$

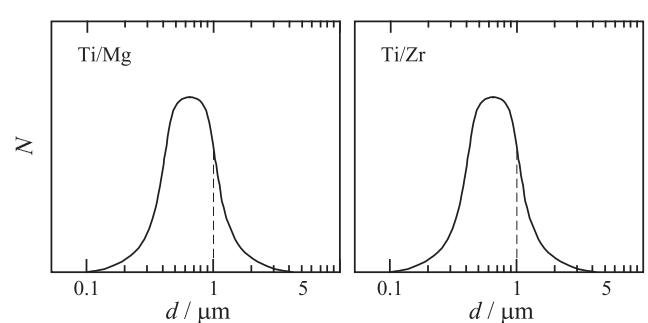

a) Size distribution of oxide particles after deoxidation

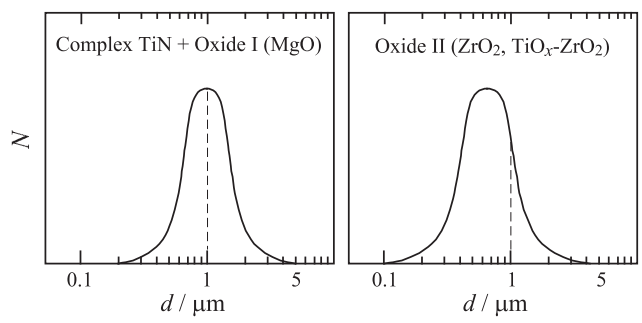

b) Before solidification

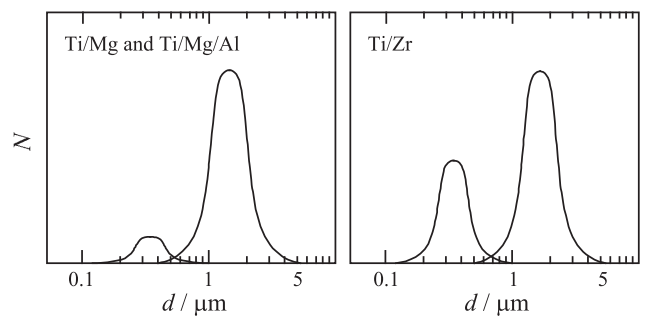

c) After solidification

Fig. 7. Schematic illustration of size distributions of oxide and complex TiN+oxide particles with high $(\mathrm{MgO})$ and low $\left(\mathrm{ZrO}_{2}\right.$ and $\mathrm{TiO}_{x}-\mathrm{ZrO}_{2}$ ) nucleation potency for TiN crystallization. crucible $>$ oxide phases in the $\mathrm{TiO}_{x}-\mathrm{ZrO}_{2}$ system.

These schematic curves shown on the top diagram of Fig. 7 correspond to the experimentally obtained results. ${ }^{8,10)}$ The middle diagrams of Fig. 7 corresponds to the size distribution before solidification, which means that TiN crystallization occurred during cooling from $1600^{\circ} \mathrm{C}$ to solidification. The size distribution of particles before solidification is affected by TiN crystallization, which depends on the surface composition of oxide particles under a given [Ti]·[N] solubility product and cooling rate. Therefore, the curves in the middle diagrams of Fig. 7 are drawn based on the difference in the nucleation potency. The size distribution shown on the lefthand side of the middle diagram of Fig. 7 corresponds to the crystallization of $\mathrm{TiN}$ on the primary $\mathrm{MgO}$ and $\mathrm{MgO}-\mathrm{TiO}_{x}$ particles. The modal value increases to $1 \mu \mathrm{m}$ and the change of the modal value depends on the size distribution of oxide particles and [Ti]·[N] solubility product. If the surface composition is not appropriate to the nucleation of TiN crystallization such as $\mathrm{ZrO}_{2}$ or $\mathrm{TiO}_{x}-\mathrm{ZrO}_{2}$, the TiN crystallization is difficult to initiate during cooling to solidification without increasing the $[\mathrm{Ti}] \cdot[\mathrm{N}]$ solubility product. This is shown on the right-hand side of the middle diagram of Fig. 7.

The bottom diagrams of Fig. 7 demonstrate the size distributions after solidification for $\mathrm{MgO}$ particles (left-hand side) and that for $\mathrm{ZrO}_{2}$ or $\mathrm{TiO}_{x}-\mathrm{ZrO}_{2}$ particles (right-hand side). It is seen that the amount of TiN precipitation for very effective nucleating particles (left-hand side) is less than that for ineffective nucleating particles under the present condition of $[\mathrm{Ti}] \cdot[\mathrm{N}]$ solubility product in which no TiN crystallization on ineffective particles occurs. If no crystallization of TiN occurs on oxide particles with low nucleation potency, the supersaturation degree of TiN crystallization ${ }^{1)}$ increases under a given [Ti]·[N] solubility product. Consequently, as shown on the

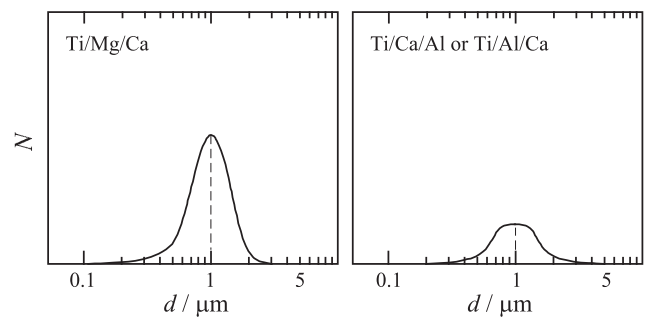

a) Size distribution of oxide particles after deoxidation

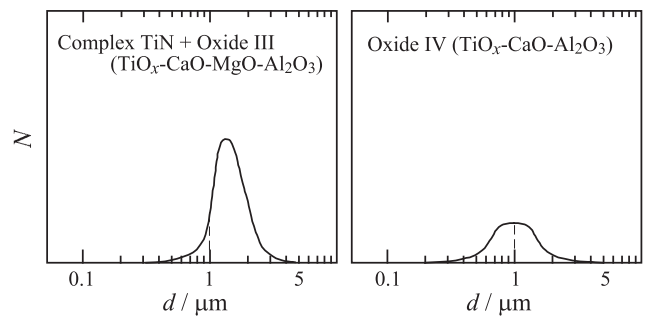

b) Before solidification

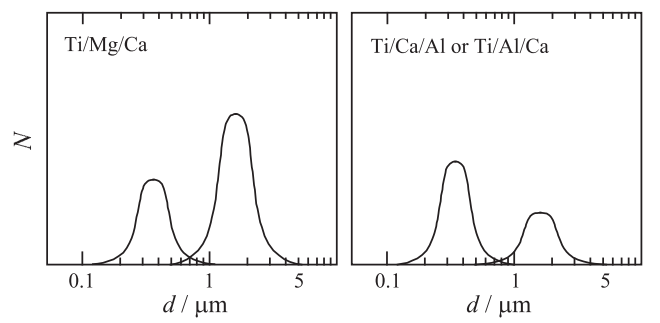

c) After solidification

Fig. 8. Schematic illustration of size distributions of oxide and complex TiN+oxide particles with high $\left(\mathrm{TiO}_{x}-\mathrm{CaO}-\mathrm{MgO}-\mathrm{Al}_{2} \mathrm{O}_{3}\right)$ and low $\left(\mathrm{TiO}_{x}-\mathrm{CaO}-\mathrm{Al}_{2} \mathrm{O}_{3}\right)$ nucleation potency for TiN crystallization. 
right-hand side of the bottom diagram, the nucleation rate of TiN precipitation increases, thereby resulting in the increase in the number of small precipitated TiN particles.

The variation of particle size distribution during cooling is schematically illustrated in Fig. 8 for Ti/Mg/Ca and Ti/Ca/ $\mathrm{Al}$ or $\mathrm{Ti} / \mathrm{Al} / \mathrm{Ca}$ deoxidations whose nucleation potency is between that in $\mathrm{Ti} / \mathrm{Mg}$ and that in $\mathrm{Ti} / \mathrm{Zr}$ deoxidation. The curves shown on the left-hand side and the right-hand side of Fig. 8 correspond to the results shown in Figs. 4 and 2, respectively. The top diagrams which correspond to the size distribution of oxide particles are drawn based on the assumption that the number of oxide particles in $\mathrm{Ti} / \mathrm{Mg} / \mathrm{Ca}$ deoxidation is greater than that in $\mathrm{Ti} / \mathrm{Ca} / \mathrm{Al}$ or $\mathrm{Ti} / \mathrm{Al} / \mathrm{Ca}$ deoxidation. This is based on the finding that the number of oxide particle decreases and the particle size increases in the order of $\mathrm{Ti} / \mathrm{Mg}>\mathrm{Ti} / \mathrm{Ca}>\mathrm{Ti} / \mathrm{Al}$ deoxidations. The middle diagrams of Fig. 8 correspond to the size distribution before solidification and these curves are drawn based on the nucleation potency of the surface composition of oxide particles. In $\mathrm{Ti} / \mathrm{Mg} / \mathrm{Ca}$ deoxidation, in which the nucleation potency of TiN crystallization is high due to the surface composition consisting of a $\mathrm{MgO} \cdot \mathrm{Al}_{2} \mathrm{O}_{3}-2 \mathrm{MgO} \cdot \mathrm{TiO}_{2}$ solid solution, the modal value shifts to the right-hand side as a result of the crystallization of TiN on oxide particles, as shown on the left-hand side of the middle diagram of Fig. 8 . The shift of the modal value is not greater compared with that in $\mathrm{Ti} / \mathrm{Mg}$ deoxidation. This is explained by the fact that the number of small $\mathrm{TiN}+\mathrm{MgO}$ particles increases more than the number of $\mathrm{TiN}+\left(\mathrm{CaO}-\mathrm{MgO}-\mathrm{TiO}_{x}\right)$ particles, under the assumption that the amount of TiN crystallization on particles is independent of the particle size. ${ }^{10)} \mathrm{In} \mathrm{Ti} / \mathrm{Ca} / \mathrm{Al}$ or $\mathrm{Ti} / \mathrm{Al} / \mathrm{Ca}$ deoxidation using an $\mathrm{Al}_{2} \mathrm{O}_{3}$ crucible, in which the nucleation potency of TiN is low, no TiN crystallization occurs, as shown on the right-hand side of the middle diagram of Fig. 8.

As shown in the bottom diagram of Fig. 8, the amount of TiN precipitation shown on the left-hand side is slightly less than that shown on the right-hand side, because the nucleation potency of the particles in $\mathrm{Ti} / \mathrm{Mg} / \mathrm{Ca}$ deoxidation is higher than that in $\mathrm{Ti} / \mathrm{Ca} / \mathrm{Al}$ or $\mathrm{Ti} / \mathrm{Al} / \mathrm{Ca}$ deoxidation using an $\mathrm{Al}_{2} \mathrm{O}_{3}$ crucible. It can be concluded that the distribution curve after solidification is affected by the effectiveness of the nucleation potency of the particle surface and [Ti]·[N] solubility product.

\subsection{Number of Primary Particles and Solidification Structure}

Three types of solidification structures observed in this study, denoted as Types A, B and C are given in Table 3 and typical solidification structures are shown in Fig. 9. Type A shows fine equiaxed crystals throughout the cross section, and Types $\mathrm{B}$ and $\mathrm{C}$ are the solidification structures in the presence and absence of equiaxed crystals in the final solidification region of the ingot, respectively. The mark (A) denotes small columnar grains and/or equiaxed crystals and columnar with small width and length.

Complex particles having a thick layer of cuboidal TiN and a thin layer or partially precipitated complex particles are denoted as complex-a and complex-b, respectively. In this section, solidification structure is discussed based on the number of TiN, oxide, complex-a and complex-b particles with sizes above $1.5 \mu \mathrm{m}$, as measured by an optical microscope. It is reasonable to assume that complex-b particles are produced after solidification, while complex-a particles are produced before solidification, if the [Ti] $[\mathrm{N}]$ solubility product is above the equilibrium value. ${ }^{7)}$ In this case, primary TiN particles and complex-a particles above $1.5 \mu \mathrm{m}$ work as nuclei for solidification.
Table 3. Types of solidification structures.

\begin{tabular}{cl}
\hline Solid. type & \multicolumn{1}{c}{ Solidification structure } \\
\hline A & \multicolumn{1}{c}{ Fine EC in whole area } \\
P-1(A) & Small CR and small EC \\
B-2 & Large EC \\
B-3 & Large CR \\
B-4(A) & Small CR \\
Absence of EC in final solidification area \\
C-1 & Very large EC \\
C-1(A) & Middle size EC \\
C-2(A) & CR with small width and length \\
C-3 & Large CR \\
C-4 & Large CR and small EC \\
C-4(A) & Small CR and small EC \\
\hline CR: Columnar grains. & \\
EC: Equiaxed crystals. &
\end{tabular}

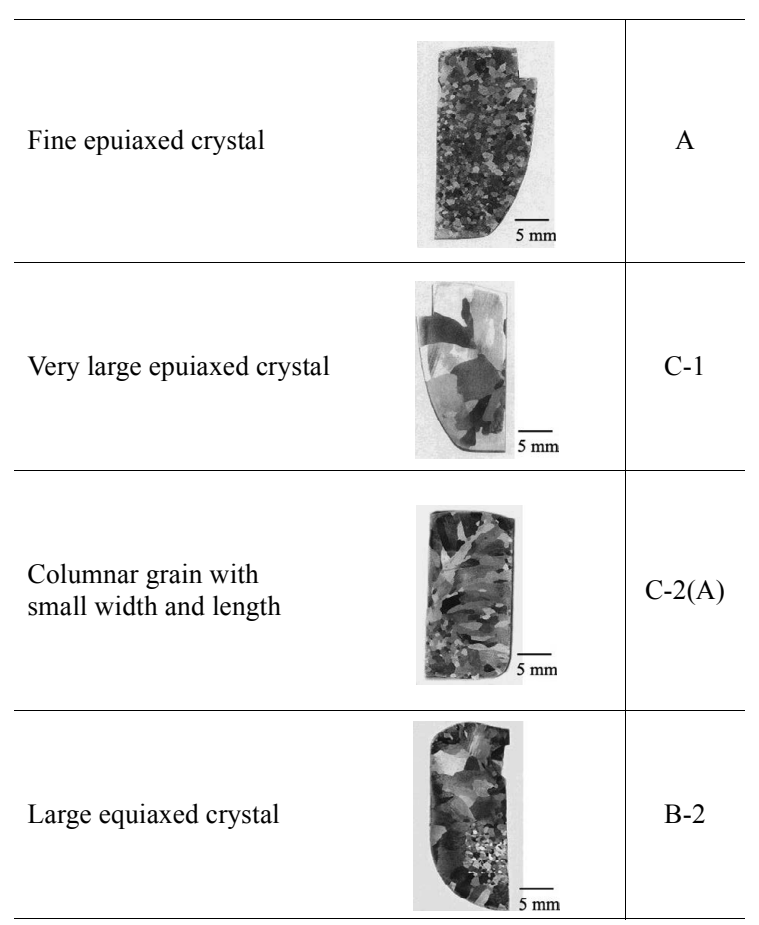

Fig. 9. Typical solidification structures.

The total numbers of TiN, complex-a, complex-b and oxide particles per unit area in three ranges of $\mathrm{N}$ content $(\geq 100,50$ to 100 and $\leq 50 \mathrm{ppm} \mathrm{N})$ are shown in Figs. 10 to 12 for the solidification structures of Types A, B and C, respectively. As shown in Fig. 10, the total numbers of TiN and complex-a particles which are supposed to work as solidification nuclei tend to decrease with decreasing $\mathrm{N}$ content from 282 to $36 \mathrm{ppm}$. The results of Exps. 12 (145 ppm $\mathrm{N}), 13(202 \mathrm{ppm} \mathrm{N}), 15(207 \mathrm{ppm} \mathrm{N})$ and 17 (267 ppm N) in $\mathrm{Ti} / \mathrm{Mg}$ deoxidation in which the Type A solidification structure was observed are not included in the figure. It is interesting to note that the Type A solidification structure was observed even with low $\mathrm{N}$ content below $80 \mathrm{ppm}$, which is lower than the equilibrium $\mathrm{N}$ content $(90(110)$ ppm for an $\mathrm{Fe}-10(20) \% \mathrm{Cr}$ alloy at $1550^{\circ} \mathrm{C}$ ) at $\mathrm{Ti}=0.3 \%{ }^{7}$ ) Therefore, the TiN and complex-a particles above $1.5 \mu \mathrm{m}$ in the $\mathrm{N}$ range below 80 ppm may not be primary particles. In the $\mathrm{Ti} / \mathrm{Mg}(\mathrm{Ca}) / \mathrm{Ca}(\mathrm{Mg})$ deoxidation, oxide, complex-a and complex-b particles which correspond to primary total oxide 


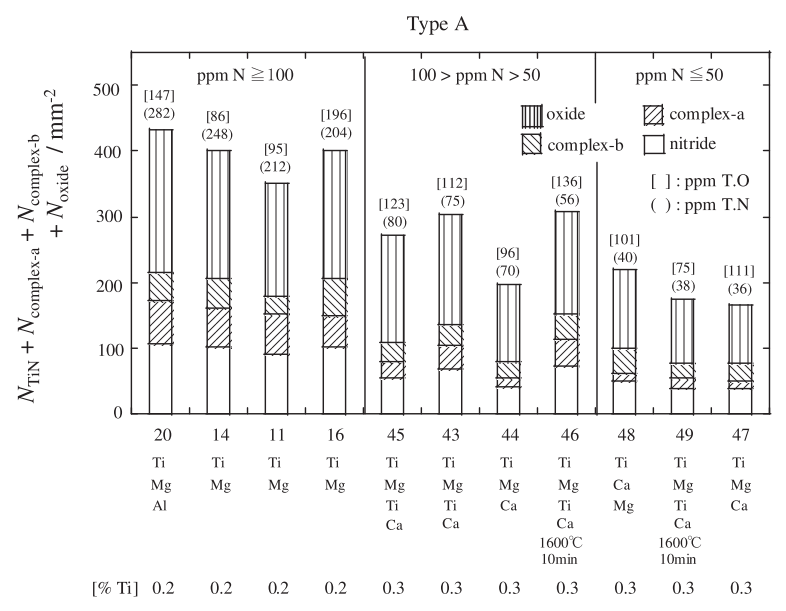

Fig. 10. Number of respective particles per unit area at solidification Type A for three different $\mathrm{N}$ ranges.

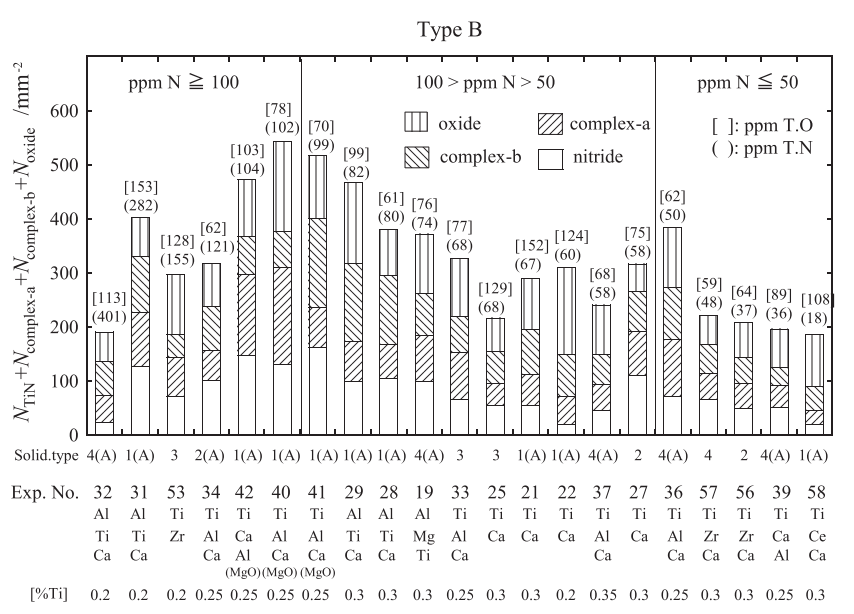

Fig. 11. Number of respective particles per unit area at solidification Type B for three different $\mathrm{N}$ ranges.

particles work as nuclei for solidification in the $\mathrm{N}$ range between 36 and $80 \mathrm{ppm}$. In Ti/Mg deoxidation, Type A is observed at $\mathrm{N}>204 \mathrm{ppm}$ and Type $\mathrm{C}$ is obtained at $\mathrm{N}<86$ ppm (Exps. 8, 10 and 18), as shown in Fig. 12. These results suggest that fine solidification structures are observed in $\mathrm{Ti} /$ $\mathrm{Mg}$ deoxidation with high $\mathrm{N}$ content and in $\mathrm{Ti} / \mathrm{Mg} / \mathrm{Ca}$ deoxidation with low $\mathrm{N}$ content.

As shown in Fig. 11 showing the Type B solidification structure and the number density of complex-a and TiN particles tend to decrease with decreasing $\mathrm{N}$ content in the range below $\mathrm{N}=100 \mathrm{ppm}$, although there are some exceptions. The reasons that no systematic trend is observed in the range above $\mathrm{N}=100 \mathrm{ppm}$ are due to the cluster formation of TiN, complex-a and complex-b particles and the formation of many small particles below $1.5 \mu \mathrm{m}$ which were not measured. The morphology of clustered particles observed on a cross-section is completely different from that of large particles. This difference was confirmed by the 3-D method and the etching method by using $10 \%$ iodine-methanol for the 2 D samples. The results for $\mathrm{Ti} / \mathrm{Ca} / \mathrm{Ti}$ ( Exp. 23: $\mathrm{N}=43 \mathrm{ppm}$ and B-1(A) ) and Ti/Ca (Exp. 24: $\mathrm{N}=37$ ppm and B-1(A)) deoxidations are not included in the figure. The number density of TiN and complex-a are nearly the same as those of Type A, but the number density of oxide particles in Type $\mathrm{B}$ is smaller than that in Type A, shown in Fig. 10 .

The results for the Type $\mathrm{C}$ solidification structure are shown in Fig. 12, in which Ti (Exp. 1: C-1) and Mg (Exp. 7: C-1(A)) deoxidations are not included in the figure. It can be seen that no linear relationship between the number den-

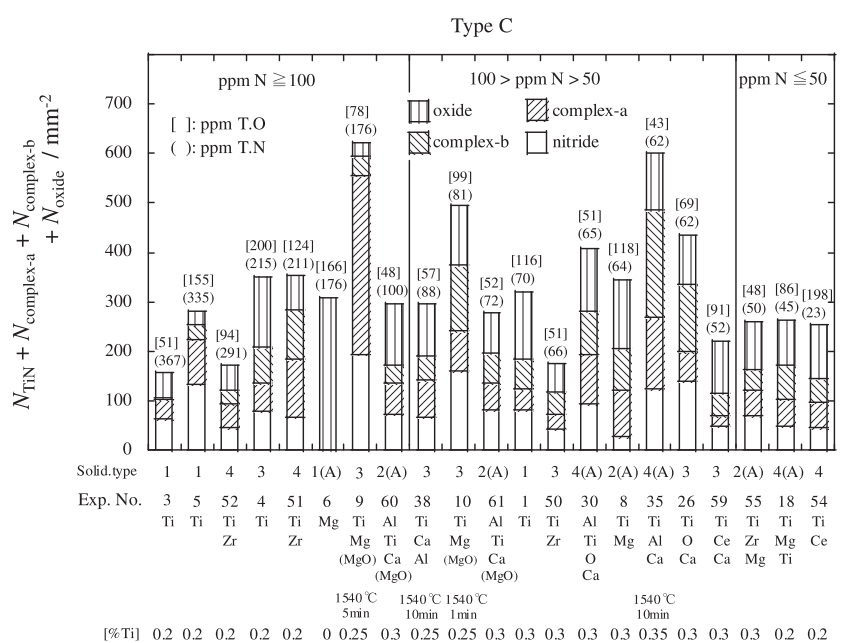

Fig. 12. Number of respective particles per unit area at solidification Type $\mathrm{C}$ for three different $\mathrm{N}$ ranges.

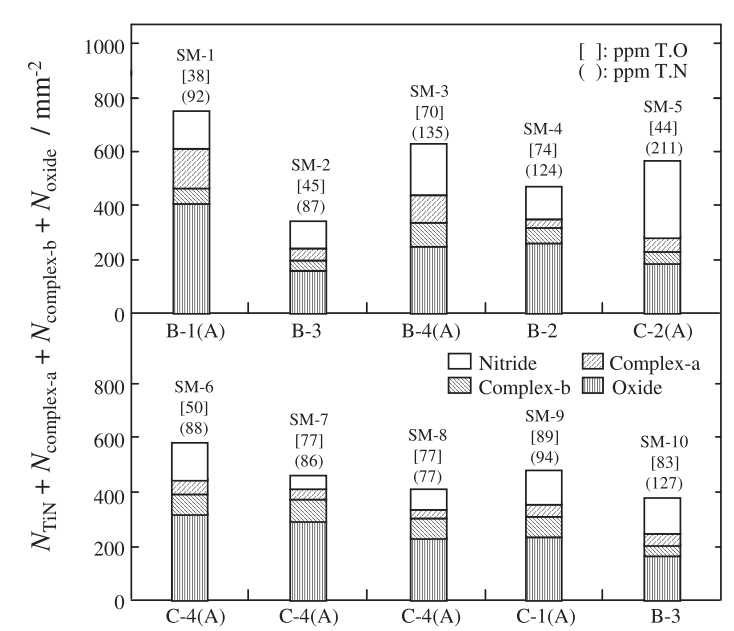

Fig. 13. Number of TiN, complex-a, complex-b, and oxide particles per unit area in deoxidation experiments with slag.

sity of TiN and complex-a particles and $\mathrm{N}$ content is obtained. Large particles of TiN, complex-a, complex-b and oxide with the size of $l_{\max }=5-15 \mu \mathrm{m}$ were observed in Ti deoxidation (Exps. 3, 4 and 5) at high $\mathrm{N}$ content above 200 ppm due to cluster formation. In $\mathrm{Ti} / \mathrm{Zr}$ deoxidation (Exps. 50 to 52), the number density of TiN, complex-a, complex-b and oxide particles below $1.5 \mu \mathrm{m}$ is considerably larger ${ }^{8,10}$ compared with other deoxidation, but these small particles could not be measured in this study.

On the basis of the results of the solidification structures of Types A, B and C, shown in Figs. 10 to 12, it can be concluded that the solidification structure is mainly related to the deoxidation method given in Table 1, although there are some exceptions. The Type A solidification structure was observed in Ti/Mg (Exps. 11 to 17), Ti/Mg/Al (Exp. 20) and $\mathrm{Ti} / \mathrm{Mg} / \mathrm{Ti} / \mathrm{Ca}$ ( $\mathrm{Ti} / \mathrm{Mg} / \mathrm{Ca}$ and $\mathrm{Ti} / \mathrm{Ca} / \mathrm{Mg}$ ) (Exps. 43 to 49 ) deoxidations. However, exceptions occurred in $\mathrm{Al} / \mathrm{Mg} / \mathrm{Ti}$ (Exp.19: B-4(A)), Mg (Exps. 6 and 7: C-1(A)), Ti/Mg (Exp. 8: $\mathrm{C}-2(\mathrm{~A})$ ), $\mathrm{Ti} / \mathrm{Mg} / \mathrm{Ti}$ (Exp.18: $\mathrm{C}-4(\mathrm{~A}))$ and $\mathrm{Ti} / \mathrm{Mg}$ (Exps. 9 and 10: C-3) deoxidations.

The Type B solidification structure was observed in $\mathrm{Ti} / \mathrm{Ca}$ (Exps. 21 to 24: B-1(A)), Al/Ti/Ca (Exps. 28, 29, 31: B1(A) and Exp. 32: B-4(A)), Ti/Al/Ca (Exp. 34: B-2(A) and Exps. 36 and 37: B-4(A)), Ti/Ca/Al (Exp. 39: B-4(A)), Ti/ $\mathrm{Al} / \mathrm{Ca}(\mathrm{MgO})$ (Exps. 40 and $41: \mathrm{B}-1(\mathrm{~A}))$ and $\mathrm{Ti} / \mathrm{Ca} / \mathrm{Al}$ $(\mathrm{MgO})$ (Exp. 42: B-1(A)) deoxidations except for $\mathrm{Ti} / \mathrm{Ca}$ (Exp. 25: B-3 and Exp. 27: B-2) and Ti/Al/Ca (Exp. 33: B- 
3). The Type $\mathrm{C}(\mathrm{A})$ solidification structure was observed in $\mathrm{Al} / \mathrm{Ti} / \mathrm{Ca}$ (Exp. 30: C-4(A) and Exps. 60 and 61: C-2(A)) and $\mathrm{Ti} / \mathrm{Al} / \mathrm{Ca}$ (Exp. 35: C-4(A)) deoxidations except for Ti/ $\mathrm{Ca}$ (Exp. 26: C-3) and Ti/Ca/Al (Exp. 38: C-3) deoxidations. It is pointed out that the solidification structures observed in $\mathrm{Ti} / \mathrm{Ca}$ and $\mathrm{Ti} / \mathrm{Al} / \mathrm{Ca}(\mathrm{Al} / \mathrm{Ti} / \mathrm{Ca})$ deoxidations using an $\mathrm{Al}_{2} \mathrm{O}_{3}$ crucible were significantly finer than these observed in only Ti deoxidation.

The Type B solidification structure was observed in $\mathrm{Ti} / \mathrm{Zr}$ (Exp. 53: B-3), Ti/Zr/Ca (Exp. 57: B-4) and Ti/Zr/Ca (Exp. 56: B-2) deoxidations except for $\mathrm{Ti} / \mathrm{Ce} / \mathrm{Ca}$ (Exp. 58: B1(A)) deoxidation. The Type $\mathrm{C}$ solidification structure was observed in Ti (Exps. 1, 2, 3, 5: C-1 and Exp. 4: C-3), Ti/ Zr (Exp. 50: C-3 and Exps. 51 and 52: C-4), Ti/Ce (Exp. 54: $\mathrm{C}-4$ ) and $\mathrm{Ti} / \mathrm{Ce} / \mathrm{Ca}$ (Exp. 59: C-3 ) deoxidations except for Ti/Zr/Mg (Exp. 55: C-2(A)) deoxidation. The solidification structures observed in $\mathrm{Ti} / \mathrm{Zr}(\mathrm{Ti} / \mathrm{Zr} / \mathrm{Mg}, \mathrm{Ti} / \mathrm{Zr} / \mathrm{Ca})$ and $\mathrm{Ti} / \mathrm{Ce}$ ( $\mathrm{Ti} / \mathrm{Ce} / \mathrm{Ca}$ ) deoxidations using an $\mathrm{Al}_{2} \mathrm{O}_{3}$ crucible were not finer than those in $\mathrm{Ti} / \mathrm{Al} / \mathrm{Ca}(\mathrm{Al} / \mathrm{Ti} / \mathrm{Ca})$ deoxidation using an $\mathrm{Al}_{2} \mathrm{O}_{3}$ crucible. These solidification structures are almost the same as that in $\mathrm{Ti}$ alone deoxidation

It is important to estimate the number of primary particles of TiN and complex-a particles in the range below $1.5 \mu \mathrm{m}$, particularly, in $\mathrm{Ti} / \mathrm{Mg} / M(M=\mathrm{Ca}$ and $\mathrm{Al})$ by using SEM with EPMA, as discussed in Sections 3.2 and 3.3. Not only the number of primary particles, but also the surface compositions of primary TiN, complex and oxide particles are important for fine solidification structure, as shown in Fig. 10. The impact of defects in the surface composition of particles on solidification structure is described elsewhere. ${ }^{6}$ )

\subsection{Effect of Slag on TiN Crystallization}

In deoxidation experiments without slag, very fine microstructures were observed in $\mathrm{Ti} / \mathrm{Mg}$ and $\mathrm{Ti} / \mathrm{Mg} / \mathrm{Ca}$ deoxidation using an $\mathrm{Al}_{2} \mathrm{O}_{3}$ crucible, and relatively fine structure was observed in $\mathrm{Al} / \mathrm{Ti} / \mathrm{Ca}(\mathrm{Ti} / \mathrm{Al} / \mathrm{Ca})$ deoxidation using a $\mathrm{MgO}$ crucible. These results suggest that the formation of $\mathrm{MgO}$-containing $\mathrm{CaO}-\mathrm{Al}_{2} \mathrm{O}_{3}-\mathrm{TiO}_{x}$ particles is a prerequisite to the formation of fine microstructure.

The purpose of the deoxidation experiments in the presence of slag was to determine the possibility of obtaining a fine structure such as that observed in $\mathrm{Ti} / \mathrm{Mg}$ and $\mathrm{Ti} / \mathrm{Mg} / \mathrm{Ca}$ deoxidations without using a $\mathrm{Mg}$ deoxidant addition. The second purpose was to study the difference in the effect of the $\mathrm{MgO}$ crucible and $\mathrm{Mg}$-containing slag on the particle composition. The solidification structure was observed as functions of $\mathrm{Al}$ content (initial additions of $0.02,0.05$ and $0.1 \%$ : SM-1 vs SM-2 and SM-3 vs SM-4), order of deoxidant addition (Ti/Al/Ca and Al/Ti/Ca: SM-5 vs SM-6 and SM-7 vs SM-8)), crucible materials ( $\mathrm{MgO}, \mathrm{Al}_{2} \mathrm{O}_{3}$ and $\mathrm{Al}_{2} \mathrm{O}_{3}$ crucible with $\mathrm{MgO}$-ring) and holding time at $1600^{\circ} \mathrm{C}(5$ and 15 minutes: SM-7 vs SM-10). The solidification structures observed in the presence of slag were compared with those in the absence of slag as follows.

The results for the number density of TiN, complex-a, complex-b and oxide particles are shown in Fig. 13, in which the solidification structure is indicated. The experimental method is given in Table 2. On the basis of the results in Fig. 13, factors affecting TiN crystallization in the presence and absence of slag are summarized as follows: The order of deoxidant addition did not affect the number density of particles in the presence or absence of slag. The solidification structure was dependent on crucible materials rather than $\mathrm{MgO}$-containing slag in $\mathrm{Al} / \mathrm{Ti} / \mathrm{Ca}$ deoxidation, but in $\mathrm{Ti} / \mathrm{Al} / \mathrm{Ca}$ deoxidation, solidification structure was more influenced by crucible materials without respect to the presence of slag. The particle number decreased with holding time due to the absorption of particles into slag, while the particle number did not change during holding time in the deoxidations without slag.

\section{Conclusions}

The size distribution of complex deoxidation particles in an $\mathrm{Fe}-17.5(11) \% \mathrm{Cr}-0.25 \% \mathrm{Mn}-0.20 \% \mathrm{Si}-0.2$ to $0.3 \% \mathrm{Ti}-$ $0.01 \% \mathrm{C}$ alloy containing 30 to $400 \mathrm{ppm} \mathrm{N}$ were measured by using the 2-D and 3-D methods. Factors affecting TiN crystallization have been discussed and following conclusions are derived:

(1) Planar size distributions of TiN, complex and oxide particles above $1.5 \mu \mathrm{m}$ were measured by using the 2-D method and those of spatial particles with different compositions above $0.1 \mu \mathrm{m}$ were measured by using the 3 -D method. True size distribution can be estimated from the 3-D method, but the separation of TiN and complex particles and the separation of complex particles consisting of thick, thin and partially crystallized TiN layer cannot be made in the 3D method.

(2) The precipitation of TiN particles with small size is encouraged when the crystallization of TiN is suppressed at high $[\mathrm{Ti}] \cdot[\mathrm{N}]$ solubility product and low nucleation potency of oxide, thereby leading to a bimodal curve. In this case, the primary and secondary particles can be estimated. Meanwhile, the precipitation of TiN particles on oxide and complex particles is encouraged at low [Ti] $[\mathrm{N}]$ solubility product and high nucleation potency of oxide, thereby leading to a curve with a single peak. In this case, the complete separation of primary and secondary particles is difficult.

(3) Refinement of the solidification structure was not influenced by the number of primary TiN and complex particles above $1.5 \mu \mathrm{m}$, but it was influenced by the deoxidation method. However, the refinement of solidification structure due to the primary particles below $1.5 \mu \mathrm{m}$, which could not be estimated in 2-D method, cannot be ruled out, particularly, for the particles with high nucleation potency of $\delta$-phase solidification. A very fine structure was observed in $\mathrm{Ti} / \mathrm{Mg}, \mathrm{Ti} / \mathrm{Mg} / \mathrm{Al}$ and $\mathrm{Ti} / \mathrm{Mg}(\mathrm{Ca}) / \mathrm{Ca}(\mathrm{Mg})$ deoxidations in an $\mathrm{Al}_{2} \mathrm{O}_{3}$ crucible, and a fine structure was observed in $\mathrm{Ti}(\mathrm{Al}) /$ $\mathrm{Al}(\mathrm{Ti}) / \mathrm{Ca}$ deoxidation using a $\mathrm{MgO}$ crucible or $\mathrm{MgO}$-containing slag.

\section{Acknowledgement}

The fruitful discussion with Dr. Sun Koo Kim, POSCO, are greatly acknowledged.

\section{REFERENCES}

1) A. Ostrowski and E. W. Langer: Scand. J. Metall., 8 (1979), 153.

2) T. Koseki and H. Inoue: J. Jpn. Inst. Met., 65 (2001), 644.

3) H. Fujimura, S. Tsuge, Y. Komizo and T. Nishizawa: Tetsu-toHagané, 87 (2001), 707.

4) K. Nakajima, H. Hasegawa, S. Khumkva and M. Hayashi: ISIJ Int., 46 (2006), 801.

5) G. V. Pervushin and H. Suito: ISIJ Int., 47 (2001), 748.

6) S.-K. Kim, H. Suito and R. Inoue: ISIJ Int., submitted.

7) J.-O. Jo, W.-Y. Kim, C.-O. Lee and J.-J. Pak: ISIJ Int., 50 (2010), 1373.

8) A. V. Karasev and H. Suito: ISIJ Int., 48 (2008), 1507.

9) H. Ohta and H. Suito: ISIJ Int., 47 (2007), 197.

10) A. V. Karasev and H. Suito: ISIJ Int., 49 (2009), 229. 